\title{
Integrated seismic ambient noise, magnetotellurics and gravity data for the 2D interpretation of the Vallès basin structure in the geothermal system of La Garriga-Samalús (NE Spain)
}

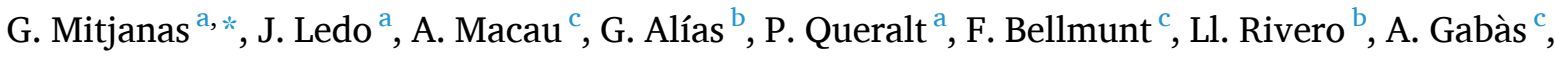 \\ A. Marcuello ${ }^{\text {a }}$, B. Benjumea ${ }^{c}$, A. Martí ${ }^{a}$, S. Figueras ${ }^{c}$ \\ ${ }^{a}$ Departament de Dinàmica de la Terra i de l'Oceà, Universitat de Barcelona, C/ Martí i Franquès s/n, 08028, Barcelona, Spain \\ ${ }^{\mathrm{b}}$ Departament de Mineralogia, Petrologia i Geologia Aplicada, Universitat de Barcelona, C/ Martí i Franquès $s / n, 08028$, Barcelona, Spain \\ ${ }^{\mathrm{c}}$ Institut Cartogràfic i Geològic de Catalunya (ICGC), Parc de Montjuïc, 08038, Barcelona, Spain
}

\section{A R T I C L E I N F O}

\section{Keywords:}

Geothermal exploration

Method combination

HVSR method

Magnetotelluric method

Gravity method

\begin{abstract}
A B S T R A C T
The integration of geophysical methods, together with the previous information of the Vallès basin area, has resulted in the creation of a new conceptual model that explains La Garriga-Samalús geothermal system. The integration of complementary geophysical methods seems to be a good option for the preliminary stages of a geothermal system exploration, especially in urban areas.

An integrated seismic ambient noise, magnetotellurics, and gravity methods were used to determine the geological units and structures which control the La Garriga-Samalús geothermal system. The 2D resistivity and density models have allowed the identification of the four main units which regulate the geothermal system: the Miocene basin, the Prelitoral Range unit, the Vallès Faut Zone, and the Paleozoic basement. The interpretation of our models set the Vallès Fault Zone, which is characterized by an anomalous low resistivity and low density, as the main path for the hot fluids. Moreover, the geophysical characterization established a new geometry for the Miocene basin. The Miocene basin presents a stepwise morphology, with the minor thickness towards the fault and an increasing thickness towards the center of the basin. This geometry seems to be related to synthetic normal faults.

These results have evidenced that, although, in some geothermal systems, the warm water may create an insufficient physical contrast; the appropriate use of some techniques can still be useful for the exploration of medium and low-temperature geothermal systems.
\end{abstract}

\section{Introduction}

The role of geophysics in the exploration of geothermal resources has been discussed in several review papers (Banwell, 1973, 1970; Bodvarsson, 1970; Manzella, 1973; Meidav and Tonani, 1976; Pálmason, 1976; Shah et al., 2015), and it has been definitely set among the main disciplines which allows the characterization and monitoring of a geothermal system (Abdelfettah et al., 2018; Chambefort et al., 2016; Hermans et al., 2014; Hunt et al., 2009; Kana et al., 2015; Peacock et al., 2013).

Geophysical exploration involves taking measurements at or near the Earth's surface that are influenced by the internal distribution of physical properties. The analysis of these measurements can reveal how the physical properties of the Earth's interior vary vertically and laterally, and consequently, interpret the geology and the structural features of the subsurface (Kearey et al., 2002). In a geothermal system context, the geophysical methods do not just allow the structural characterization of the subsurface, key parameters like temperature or fluid content, can be also indirectly estimated by their utilization (Georgsson, 2009; Leeuwen, 2016; Shah et al., 2015).

In recent years, geothermal exploration has put the spotlight on urban areas. (Di et al., 2006; Lüschen et al., 2014; Moeck et al., 2015; Yousefi et al., 2019; Zhang et al., 2012). This renewable energy has an enormous potential in populated regions, where the demand is continuously growing and there is a need of reducing the reliance on highly polluting energies (Kraft et al., 2009; Schiel et al., 2016). In this

\footnotetext{
* Corresponding author.

E-mail address: gmitjanas@ub.edu (G. Mitjanas).
} 
geographical context, the development of geophysical surveying, properly applied, can optimize exploration programs by maximizing the rate of ground coverage and minimizing the drilling requirement (Kearey et al., 2002). Hence, urban areas are set as an important geographical context to apply the geophysical methods for geothermal exploration, but not in all the geological contexts their application would have great results. The physical property contrast in the subsurface of the study area would condition the quality of the geophysical results (Benson et al., 2003).

Most of the geophysical prospections in geothermal exploration are related to high-temperature geothermal systems (fluid temperature $>150{ }^{\circ} \mathrm{C}$ ), which are commonly found in exceptional geological areas, like volcanic or seismically active areas (Jousset et al., 2011; Khodayar and Björnsson, 2014). The hydrothermal alteration products or also the high-temperature contrast can allow an easy characterization of this kind of system by using geophysical methods (Maithya and Fujimitsu, 2019; Rodríguez et al., 2015). However, in medium and low-temperature systems, sometimes there is an insufficient physical contrast from the host rock to easily detect the geothermal reservoir or to detect its consequence alteration cap (Soengkono et al., 2013). Even that, geophysical methods are still useful to characterize the geothermal system by its geological characterization as well as the detection of some conditioning factors, for example, the fractured zones (Arango-Galván et al., 2011; Nieto et al., 2019; Thanassoulas and Xanthopoulos, 1991).

Two of the geological contexts in which geophysical methods can play an important role in medium-temperature geothermal systems are: systems related to sedimentary basins (Viseras, 2002) and systems related with fractured crystalline rocks (Lewis and Haeni, 1987). Previous studies (Calcagno et al., 2014; Mahajan et al., 2011; Rao, 1986) showed that different physical properties such as density or acoustic impedance reveal a great contrast between the basement and the sedimentary basin. Likewise, in fractured crystalline rocks, different physical properties, e.g. the electrical resistivity, can show a great contrast between the fractured and the fresh crystalline rock (Kirkby et al., 2016; Lewis and Haeni, 1987; Mandal et al., 2019; Thanassoulas and Xanthopoulos, 1991). In this way, geophysical methods allow a preliminary delimitation and characterization of the geothermal reservoir, which is essential for the determination of the system magnitude.

Moreover, the use of geophysical methods in heterogenous media may be particularly challenging. This is because the inversion process of geophysical data is inherently non-unique, hence, a variety of Earth models may fit the data equally well. Even so, as it has been demonstrated in previous studies (Ars et al., 2019; Gabàs et al., 2016; Gallardo et al., 2012; Garambois et al., 2002; García-Yeguas et al., 2017; Low et al., 2020; Mandal et al., 2019), the combination of different physical properties allows a better constraining of the models, and the interpretation can be greatly improved.

In the region of interest, the Catalan Coastal Ranges (NE Spain), several hot springs with different chemical composition and different sources can be found. Particularly, in La Garriga town there are several bicarbonate-sodic hot springs in which water comes out at temperatures of around $60^{\circ} \mathrm{C}$. A few kilometers from those hot springs $(2-3 \mathrm{~km})$, in Samalús village, a slight thermal anomaly $\left(17-22^{\circ} \mathrm{C}\right)$ was detected in some open shallow wells (10-26 m) (IGME, 1977). For this reason, during the 80 's, and due to the growing interest in geothermal energy, six exploratory boreholes were made in Samalús area by the Geological Survey of Spain (IGME, 1986, 1984a, 1982). These boreholes allowed a first characterization of the lithologies as well as a temperature gradient estimation. Temperatures of around $90{ }^{\circ} \mathrm{C}$ were recorded at $1000 \mathrm{~m}$ depth (IGME, 1986). Currently in La Garriga-Samalús area, several spas benefit from these hot waters.

Although several works about this geothermal system were published after the boreholes construction (Canals et al., 1989; Cardellach et al., 2003; Fernàndez and Banda, 1990, 1988), many important aspects, such as the Vallès fault and the Miocene basin geometries, or the system which controls the circulation of hot water, are still poorly understood.

Thus, in order to bring new light to those questions we propose an integrated geophysical survey using $\mathrm{H} / \mathrm{V}$ spectral ratio of seismic ambient noise (HVSR), magnetotelluric (MT) and gravity methods for the sub-surface characterization of La Garriga-Samalús geothermal system, in the Vallès basin (NE Spain). The derived physical properties, as the acoustic impedance, electrical resistivity, and density, will be used to characterize the basin geometry and the main fluid paths.

\subsection{Geological setting}

The Catalan Coastal Ranges (CCR), in the NE of Spain, constitute the onshore expression of the northeastern sector of the margin, which separates the thinned continental crust of the Valencia trough from the thickened crust of the Iberian plate (Gallart et al., 1990; Vidal et al., 1995). In this sector, the crust displays a well-developed horst and graben structure, composed of several NE-SW to ENE-WSW striking blocks. The two longitudinal mountainous chains of the CCR are the Prelitoral and Litoral ranges, which are separated by the Vallès-Penedès half-graben (Fig. 1).

Our study area is located in the CCR northeastern limit, where the Prelitoral range is limited from the Vallès basin by the Vallès normal fault. In this area, the main geological units are the Hercynian granodiorite which thrusts Paleozoic materials of the Montseny massif, and the Miocene deposits of the Vallès basin (Fig. 2). During the Paleogene extension, the Vallès fault was active and the basin was fed largely from the Prelitoral range, forming Miocene alluvial fans. In our study area, these deposits are the proximal facies of alluvial fans (Cabrera, 1981), constituted by conglomerates, sandstones and arkosic clays, which sometimes include granitic and Paleozoic boulders (IGME, 1985).

Few available seismic profiles exist around the major structure, the Vallès normal fault, but they are mostly located in the center of the

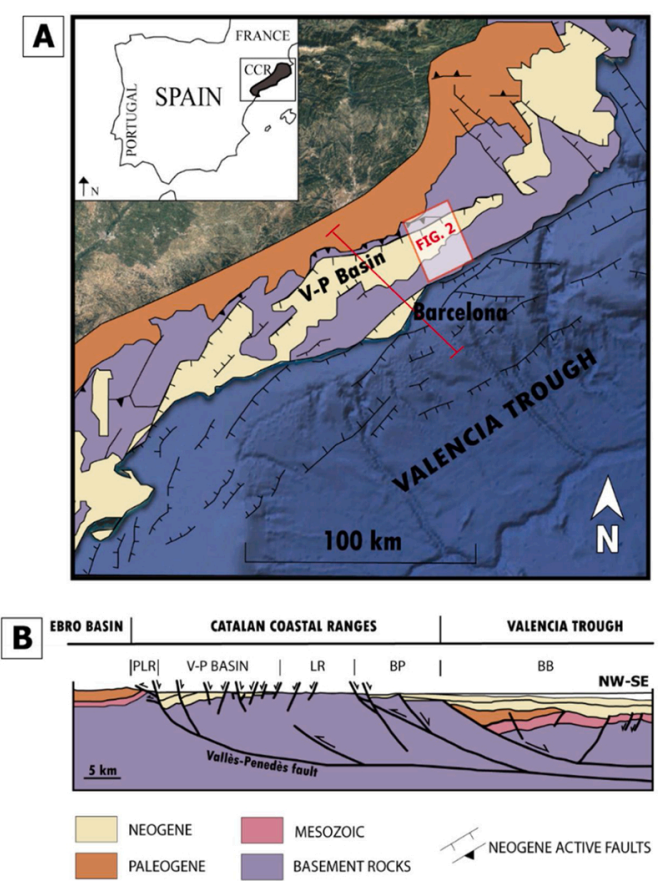

Fig. 1. A) Structural map of the Valencia trough, showing the CatalanValencian domain (modified from Martí et al., 1992). The red line indicates the location of the cross-section (B). The red square localizes the study area (see Fig. 2). B) Cross section of the Catalan Coastal Ranges and the Valencia trough (modified from Santanach et al., 2011). (V-P: Vallès-Penedès; PLR: Prelitoral range; LR: Litoral range; BP: Barcelona Plain; BB: Barcelona Basin). (For interpretation of the references to colour in this figure legend, the reader is referred to the web version of this article). 

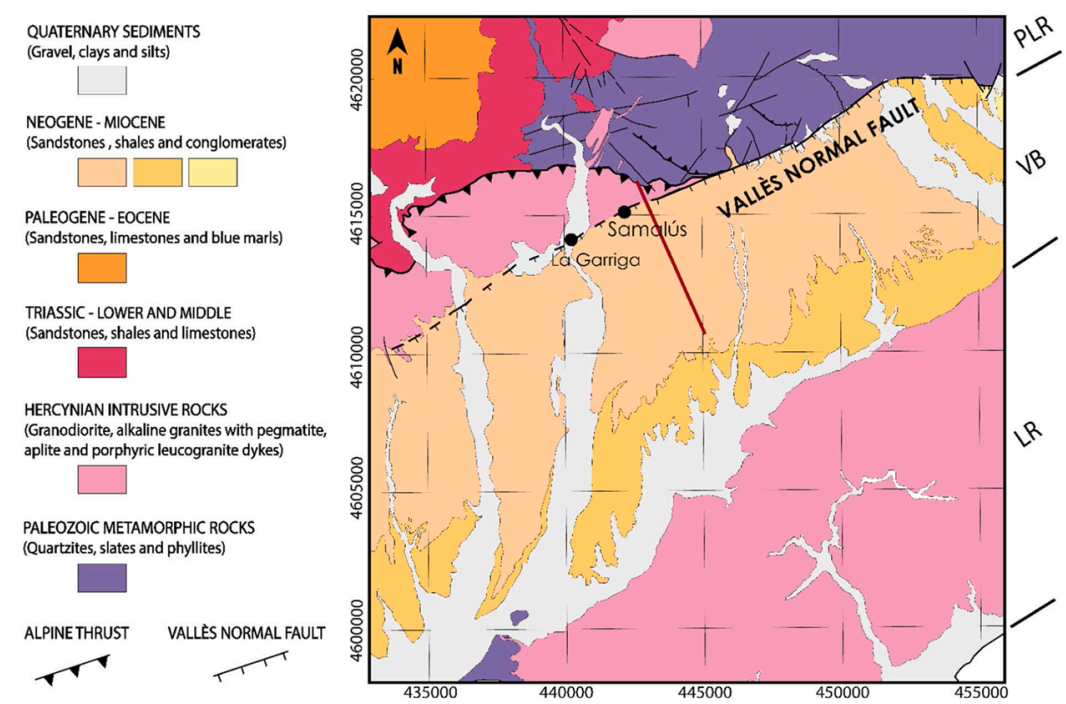

Fig. 2. Geological map of the studied area 1:50.000 (modified from ICGC, 2006) (PLR: Prelitoral range; VB: Vallès basin; LR: Litoral range).

Vallès-Penedès basin, significantly far from our study area (Gaspar-Escribano et al., 2004; Roca et al., 1999; Santanach et al., 2011). In these seismic interpretations, the Vallès fault is characterized by a listric geometry with the consequent roll-over in the Pliocene-Miocene hanging-wall (Roca et al., 1999; Sàbat et al., 1997); and also characterized by a detachment depth located in the lower/upper crust boundary (13-15 km) (Bartrina et al., 1992; Roca and Guimerà, 1992). All these previous authors identified the major thickness of the Miocene deposits next to the fault, which in some areas reaches up to $3000 \mathrm{~m}$. Several later works extrapolated this roll-over geometry from the center of the Vallès-Penedès basin to the Vallès northeastern limit, near our study area (Canals et al., 1989; Cardellach et al., 2003; Fernàndez and Banda, 1990, 1988).

The main local knowledge of La Garriga-Samalús area comes from the geothermal prospection made by the Geological Survey of Spain (IGME) during the 70's and the 80's (IGME, 1986, 1985, 1984b, 1984a, 1982, 1977). Due to the presence of some hot springs which evidenced a geothermal reservoir, they constructed six exploration boreholes in Samalús village (Fig. 3). After that, they were able to characterize the sedimentary rocks of the Miocene basin as intercalations of arkosic sandstones and shales, and discordant conglomerates; as well as the basement rock, which was mainly a granitic column (IGME, 1986). They also intersected the Vallès fault, integrated by hydrothermal cataclasites, and with a fault plain dip between 73 and 75 degrees. Of all the boreholes reports, it is worth highlighting the S3 and S6 results.

The S3 borehole (600 m deep) (IGME, 1984a) was located a bit farther from the fault trace. It did not intersect the fault plain, and hence, neither the cataclastic basement rock. Nevertheless, it showed
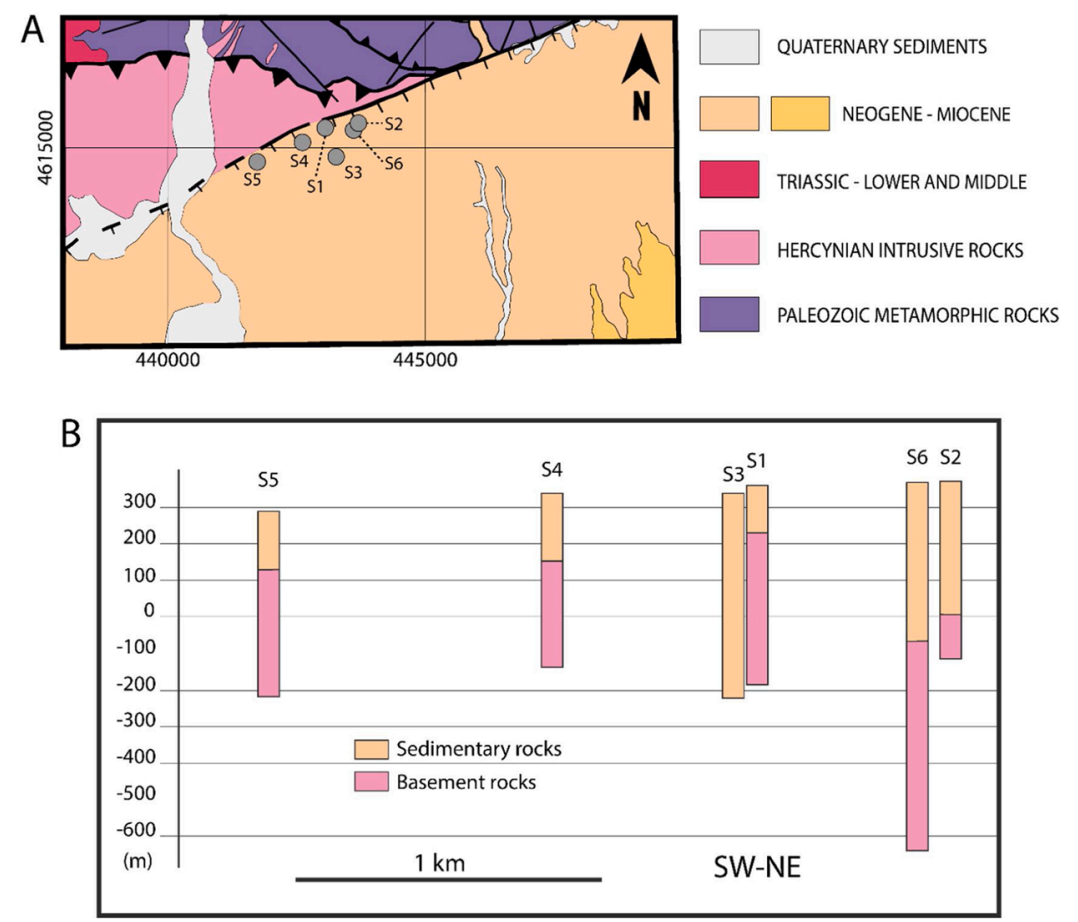

Fig. 3. A) Location of the geothermal exploration boreholes (IGME, 1986, 1984a, 1982). B) Basin-basement limit in some of the exploration boreholes. The S3 borehole (of $558 \mathrm{~m}$ ) did not ridge the basement. 
interesting results, noting that the deeper and permeable parts of the Miocene basin, were also saturated in hot water $\left(60^{\circ} \mathrm{C}\right)$. This hot water is not set as thermal water, it would be meteoric water warmed by thermal conduction (IGME, 1984a).

The S6 borehole was the deepest (IGME, 1986), and measured $90{ }^{\circ} \mathrm{C}$ at $1000 \mathrm{~m}$ depth. Studies of geothermometry and fluorite inclusion suggested that the maximum temperature of the geothermal system can be as high as $130{ }^{\circ} \mathrm{C}$ (IGME, 1986).

The actual geological model is characterized by a sub-vertical normal fault and a horst structure in the middle of the Vallès basin (Granollers horst) (Fig. 4A). This horst structure divides the basin in two parts: the northwestern sub-basin, which would have more than $3000 \mathrm{~m}$ thickness next to the Vallès fault, and the southeastern one, with $2000 \mathrm{~m}$ thickness (IGME, 1985). The preliminary study by the Geological Survey of Spain included a geoelectrical, gravity and seismic prospection in which they detected a resistive horizon between $200-500 \mathrm{~m}$ depth, in contact with the fault. This resistive layer was interpreted as compacted conglomerates (IGME, 1977) instead of crystalline basement. So in later works (IGME, 1986, 1984a) they assumed that the fault is an unique plain and that the resistive body is the conglomeratic layer, although any of the boreholes did not prove the model.

After the IGME studies, this geological model has been used to understand the geothermal system of La Garriga-Samalús, which is defined as a "forced convection" geothermal system (Fernàndez and Banda, 1988). In this kind of systems, where the thermal gradient is set as a "normal", the descending path needs to be deep and slow in order to provide high fluid temperatures. So, meteoric water would infiltrate down to several kilometers in the Prelitoral range (PLR), and then, the cataclastic granite zone in the Vallès fault core would allow a rapid ascent of the fluid (Fig. 4B), which is required to minimize conductive heat loss along the flow path. (Fernàndez and Banda, 1988; Sanchez-Guzman and Garcia De la Noceda-Marquez, 2005).

To sum up, both the general and local structural schemes of the area are characterized by a significant fault displacement (of at least $3 \mathrm{~km}$ ), showing an important Miocene deposit thickness next to the fault. As explained below, our results challenge the current conceptual model of the system represented in Fig. 4.

\section{Geophysical data acquisition and processing}

Three complementary geophysical methods, H/V spectral ratio of seismic ambient noise (HVSR), magnetotellurics (MT), and gravity, have been used to characterize the subsurface structural geology which condition the geothermal system of La Garriga-Samalús. Each of these methods deals with different physical properties (acoustic impedance, electrical resistivity, and density), which allow us high detection capacities of different system elements. In Table 1 we present the three methods with the related physical parameter, and their main uses in
Table 1

Geophysical method, parameter of interest, and main uses in geothermal exploration (Georgsson, 2009; Hersir and Bjornsson, 1991; Kana et al., 2015).

\begin{tabular}{lll}
\hline HVSR & MT & Gravity \\
Seismic velocity & Electrical resistivity & Density \\
\hline - Basin-basement boundary & - Rock composition & - Rock composition \\
- Faults delineation & - Fracturing and porosity & - Subsurface structure \\
& - Alteration of the rocks & - Porosity \\
& - Water saturation & - Saturation of rocks \\
& - Salinity of the fluid & \\
& - Temperature & \\
\hline
\end{tabular}

geothermal exploration.

With the aim of constructing a new 2D conceptual model of the geothermal system and characterizing its structure, we have used these geophysical data and three deep exploratory boreholes (IGME, 1986, 1984a, 1982). Both MT and HVSR stations are located along the same profile (Fig. 2), which is $6 \mathrm{~km}$ long, and has an NNW-SSE orientation. Although the gravity stations cover an area, the final 2D density model will be also on the same profile.

\section{1. $H / V$ spectral ratio data}

The horizontal-to-vertical spectral ratio technique applied to seismic ambient noise recordings (Bard, 1999; Nakamura, 1989) allows to identify large impedance contrasts between sediments and underlying bedrock, and determine the soil fundamental frequency. This frequency $\left(\mathrm{f}_{0}\right)$ is related to the average shear-wave velocity for the soil column (Vs) and the overburden thickness $(\mathrm{H})$ using the following expression (Bard, 1985):

$f_{0}=\frac{V_{S}}{4 \cdot H}$

Therefore, the soil fundamental frequency distribution is an indicator of the bedrock geometry in the area: a decrease in the soil fundamental frequency corresponds to an increase in the bedrock depth.

The main requirement in applying $\mathrm{H} / \mathrm{V}$ method to calculate the sediments fundamental frequency $\left(f_{0}\right)$ is that there must exist a sharp acoustic impedance contrast between sediments and bedrock, being the basement rock acoustic impedance at least twice than the sedimentary one (Fäh et al., 2001; Lachet and Bard, 1994). This method, originally used in seismic microzonation studies, can rapidly provide a robust estimate of the basement-basin limit depth and its geometry (Ibs-Von Seht and Wohlenberg, 1999).

For this experiment, 25 sites of HVSR measurements were recorded using a SARA SL06 datalogger connected to one Lennartz 0.2 Hz LE-3D/ $5 \mathrm{~s}$ three-component seismometer. The length of the seismic noise records ranges between 10 and $70 \mathrm{~min}$, depending on the expected
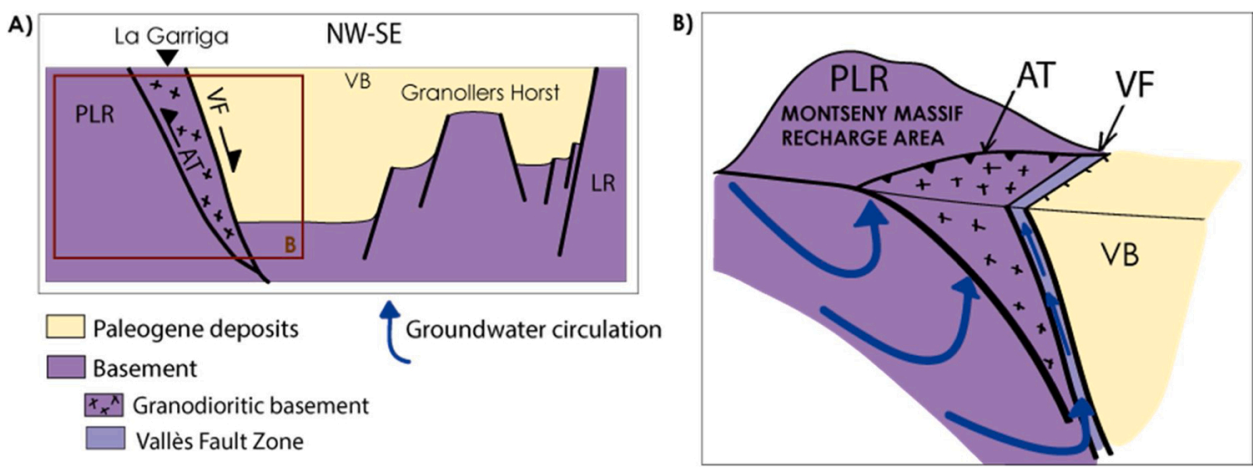

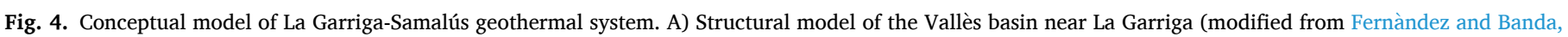

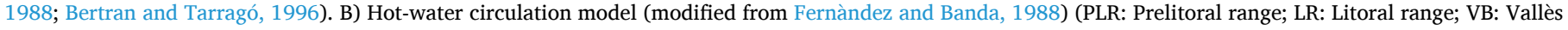
basin; VF: Vallès fault; AT: Alpine thrust). 
bedrock depth. The sampling frequency was fixed at $200 \mathrm{~Hz}$. The average distance between the seismic noise measurement points was about $300 \mathrm{~m}$. The H/V curves were calculated using the Geopsy software (http://www.geopsy.org), following this expression:

$\frac{H}{V}=\frac{\sqrt{\frac{S_{N S}^{2}+S_{E W}^{2}}{2}}}{S_{v}}$

where $S_{\mathrm{NS}}, S_{\mathrm{EW}}$ and $\mathrm{S}_{\mathrm{V}}$ are the magnitudes of the spectrum Fourier method of north-south, east-west and vertical components, respectively. The Fourier spectrum for each component was smoothed in overlapped windows by $50 \%$. Anthropogenic noise was removed using a STA/LTA antitrigger algorithm (Lee and Stewart, 1981). The criteria used for the interpretation of the H/V peaks have followed the guidelines of the Site Effects Assessment using Ambient Excitations (SESAME) project (Bard and SESAME-Team, 2004).

\subsection{Magnetotelluric data}

The magnetotelluric method (MT) involves measuring the temporal fluctuations of the horizontal components of the natural electromagnetic field at the Earth's surface to infer the lateral and vertical variations of electrical conductivity of the Earth's interior (Chave et al., 2012). Magnetotelluric data were acquired at 16 sites along an NNW-SSE profile of approximately $6 \mathrm{~km}$ length from the Prelitoral range and across the Vallès basin in 2016, with the stations placed in rural areas, $2-3 \mathrm{~km}$ away from the main city, La Garriga. The site spacing ranges between 100 and $600 \mathrm{~m}$. Measurements were carried out using the multichannel geophysical measurement system Metronix-ADU06 and Metronix-ADU07, using two induction coil magnetometers MFS-06 and four non-polarizable electrodes forming two dipoles in two orthogonal directions (N-S and E-W). The distance between electrodes of each dipole was around $50 \mathrm{~m}$ for all the stations. Natural electromagnetic field fluctuations were recorded at each site between 3 and $12 \mathrm{~h}$, using sampling frequencies of $128 \mathrm{~Hz}$ and $4096 \mathrm{~Hz}$.

The MT data was acquired near an urban area, with an intensive industrial and farming activity, what induces the presence of cultural noise. The most common sources of cultural noise are power lines and stations, electrified railways, electrified fences, power generators, and the corrosion protection systems used in oil and gas pipelines (Szarka, 1988); and all these sources are present in the Vallès basin. To detect and characterize this cultural noise, the time series were analyzed in the time-frequency domain. We considered that the cultural noise sources, in contrast to natural sources, generate an electromagnetic signal which is linearly polarized in a specific direction (Junge, 1996; Szarka, 1988; Zonge and Hugues, 1991), which allows us to distinguish between both kinds of signals. In order to work in the time-frequency domain, the data were processed using a Wavelet Transform-based scheme (Escalas et al., 2013). After the identification of the time and frequency intervals which are mostly affected by cultural noise, we discarded them from the temporal series, and thereby, reduced the noise sources effect. Figs. S1 and S2 (supplementary material) show a scalogram of the electric field at different times, and the comparison between apparent resistivities and phases with and without the noisy time series.

During data processing, we also used the remote reference technique (Gamble et al., 1979). For this technique, we used a magnetotelluric station that is less affected by cultural noise or that its cultural noise is not related to the measuring station's noise. Correlating the remote and measuring signals we obtained an increment in the signal-to-noise ratio. The final impedance tensor components were obtained for the period range $0.001-10 \mathrm{~s}$. To retrieve the strike of the regional structures and the regional impedance tensor, we followed the scheme of McNeice and Jones (2002), based on the Groom and Bailey decomposition method (Groom and Bailey, 1989). Considering an error floor for the impedance components of $5 \%$, we obtained a value of the regional strike of N60E. This value agrees with the main geological strike of the studied zone.
Decomposition RMS misfits below 2 (Fig. 5) are considered reliable and indicative that a $2 \mathrm{D}$ model interpretation of the data is appropriate. Moreover, the regional strike of the multi-site multi-frequency impedance tensor decomposition is consistent with the strike of the main geological structures of the zone. The $2 \mathrm{D}$ impedance tensor was subject to stringent quality control. The aim of this control is removing low-quality points; therefore, they would not be included in the inversion process.

\subsection{Gravity data}

The gravity map covers an area of $110 \mathrm{~km}^{2}$ with 354 gravity measurements, 214 of which were newly acquired (Fig. 6A). We used previous available Bouguer anomaly data from the Gravity Map of Catalunya 1:250 000 (IGC, 2012) (113 sites) and from a master's thesis coordinated by the Catalan Geological Survey (ICGC) (27 sites).

The new gravity sites were acquired during 2019, around La GarrigaSamalús area. The distances between all the measurement points range between 50 and $200 \mathrm{~m}$, with most of the measuring stations located along forest roads. This irregular distribution was caused by the difficult access to some parts of the area. Even so, we got a high density of sites near the profile, where the HVSR and MT measurements were carried out.

For the acquisition, we used a Lacoste \& Romberg gravity meter, and the bases employed belong to the Fundamental Gravimetric Network of Spain, originated from the International Gravity Standardization Network (IGSN 71) (Casas et al., 1987; Morelli et al., 1972).

Likewise, the most important correction made in this area with a significant topography is the terrain correction. Its procedure is based on the Hammer zones (Hammer, 1939) which in this case we have set to the standard distance, $167 \mathrm{~km}$ (Nowell, 1999). The terrain correction was made using the Gravity and Terrain Correction extension of Geosoft Oasis Montaj Programs (2008), which allows the calculation of the regional terrain correction from a coarse regional Digital Elevation Model (DEM) draped over a more finely sampled local DEM. This produces a regional correction grid which represents terrain corrections beyond a local correction distance, and this can be re-used to calculate detailed corrections at each observed gravity location. This process uses a combination of the methods described by Kane (1962) and Nagy (1966).

Considering the great variety of lithologies present, each with a particular range of densities, it was decided to employ a single reduction density corresponding to the mean density of the upper crust (Simpson and Jachens, 1989). Thus, the Bouguer anomalies were computed using a reduction density of $2.67 \mathrm{~g} / \mathrm{cm}^{3}$. The ellipsoid adopted for the calculation of theoretical gravity was the WGS84, which includes corrections caused by attraction produced by atmospheric mass.

From the Bouguer anomaly value of every site, the Bouguer anomaly map was interpolated (Fig. 6B). This map contains all the gravity anomaly effects generated by the crustal structure and other effects generated by shallower local structures with enough density contrast. As our objective was to define the near surface structure, we decomposed the Bouguer anomaly into a regional component and a residual component. This separation was carried out by assimilating the regional

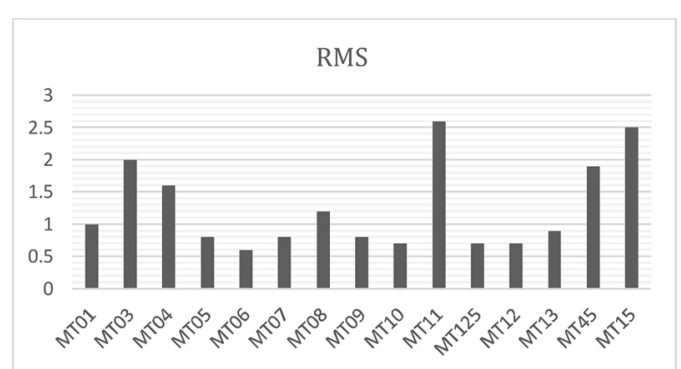

Fig. 5. RMS error of each individual MT site fitting the regional strike of N60E. 

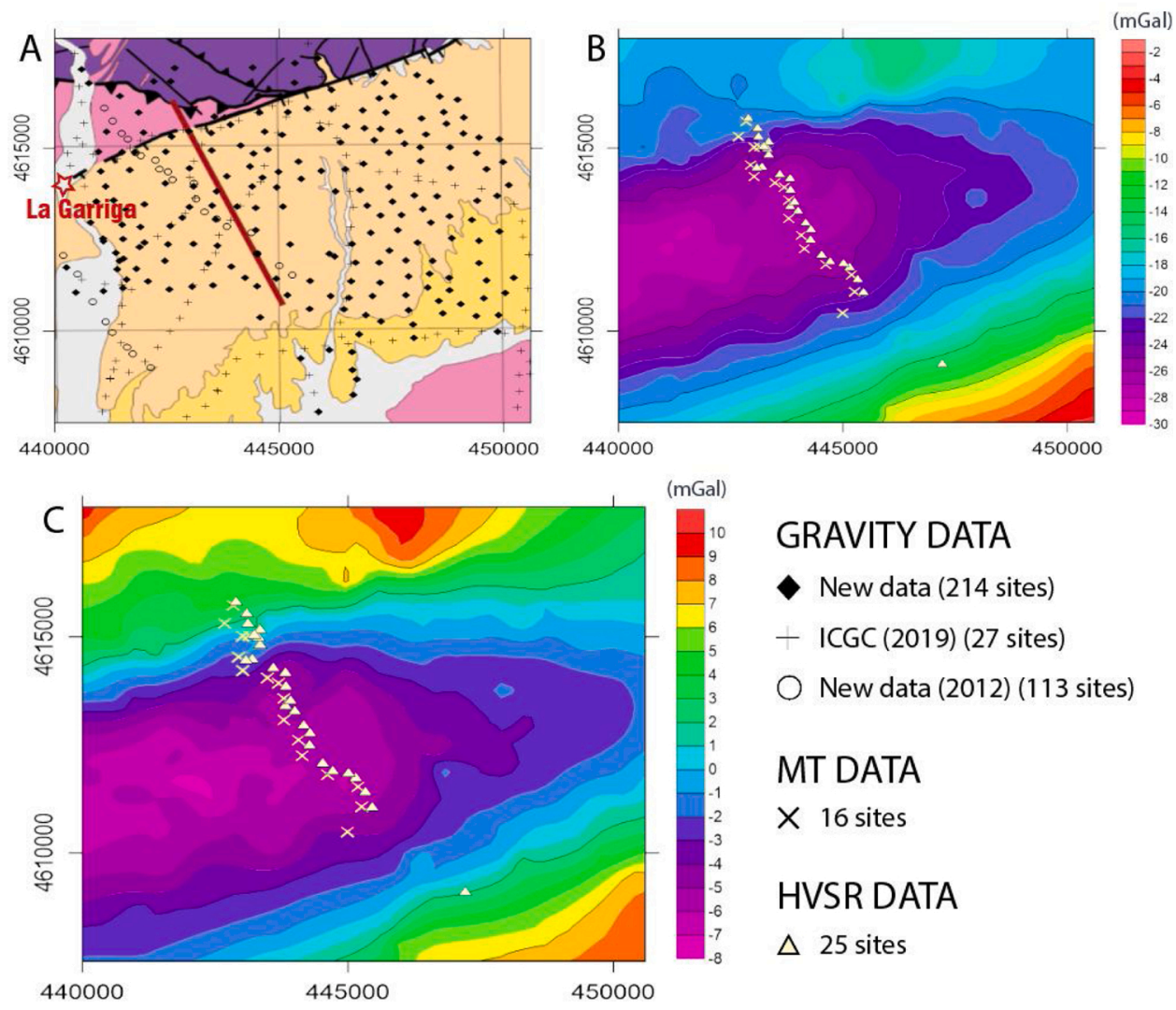

\title{
GRAVITY DATA
}

- New data (214 sites)

- ICGC (2019) (27 sites)

New data (2012) (113 sites)

\section{MT DATA}

\author{
$\times 16$ sites
}

\section{HVSR DATA}

\section{$\triangle 25$ sites}

Fig. 6. A) Geological map with the gravity sites and the location of the profile. B) Bouguer anomaly map with the MT and HVSR sites. C) Residual anomaly map with the MT and HVSR sites.

anomaly to a first-degree polynomial surface, and therefore assuming the NE-SW trending of the Catalan Coastal Ranges.

The Residual Anomaly map (Fig. 6C) illustrates a large negative anomaly with an ENE-WSW direction. This anomaly reaches $-8 \mathrm{mGal}$ over the center of the Vallès basin. Towards the north, there is a high slope with higher values, reaching $10 \mathrm{mGal}$. From the negative anomaly to the south, the values increase slightly more gradually, as well as towards the NE.

\section{Inversion and results}

\section{1. $H / V$ spectral ratio}

We have obtained the $\mathrm{H} / \mathrm{V}$ ratio curves at each measurement point. Most of them (23 sites) show a clear peak related to the soil fundamental frequency at each site. However, in two cases the $\mathrm{H} / \mathrm{V}$ spectral ratio shows a flat curve without any significant peak, indicating that the basement crops out or is very shallow. Fig. 7A shows the soil fundamental frequency values across the study profile, evidencing a clear distribution. The minimum of $0.21 \mathrm{~Hz}$ (red dots in Fig. 7A) is in the south-east of the profile, close to the center of the basin. From this point,

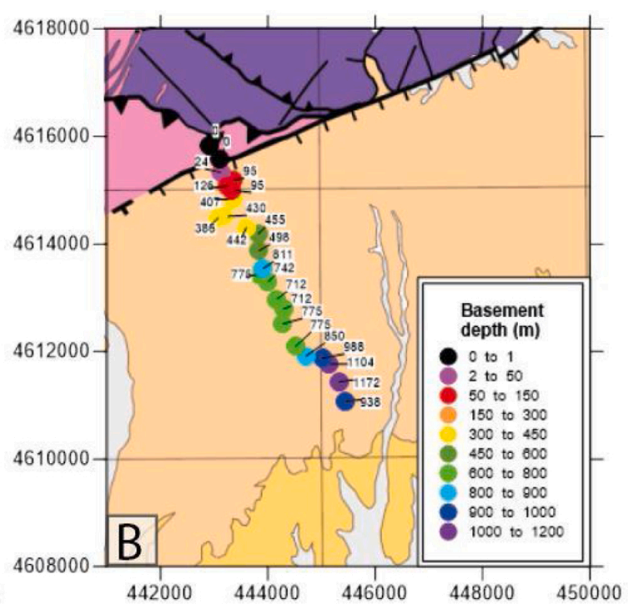

Fig. 7. A) Soil fundamental frequency values obtained from HVSR throughout the study area. B) Basement depth calculated from soil fundamental frequency using the relationship proposed by Ibs-Von Seht and Wohlenberg (1999). 
the soil fundamental values increase towards the northwest, as we get closer to the Vallès fault, reaching a maximum of $4.4 \mathrm{~Hz}$ (blue dots in Fig. 7A). The sites without significant peaks (black points in Fig. 7A) are located northwest of the Vallès fault, in a probably rocky area. Thereby, we can get a first draft of the soil-rock boundary geometry based on the soil fundamental frequency values, which shows that the deepest basement would be in the center of the basin and the shallowest would appear near the Vallès fault.

The next step will be the conversion of the soil fundamental frequency $\left(f_{0}\right)$ to basement depth $(H)$. When shear-wave velocity information is available, the most straightforward method is to apply expression (1) to calculate sediment thickness. Usually, the shear-wave velocity profiles are not known. In this case, we can obtain basement depth using an empirical relationship between $\mathrm{H}$ and $\mathrm{f}_{0}$ (Ibs-Von Seht and Wohlenberg, 1999):

$\mathrm{H}=\mathrm{a} \cdot \mathrm{f}_{0}^{\mathrm{b}}$

where $a$ and $b$ are empirical parameters strongly dependent on geological conditions, specifically on shear-wave velocity profiles. In most cases, bedrock depth was directly measured from boreholes, but it could also be calculated from the geophysical methods. The bibliography shows different empirical laws fitted in different geological environment: Ibs-Von Seht and Wohlenberg (1999) estimated in a deep Tertiary basin; Delgado et al. (2000) computed in a thin Quaternary deposits or Benjumea et al. (2011) calculated in a weathered granitic area.

This methodology has been applied in several Neogene basins near the Vallès basin (Benjumea et al., 2014; Gabàs et al., 2016; Macau et al., 2018). In these studies, the HVSR results have been compared with other geophysical exploration methods (seismic noise array technique, magnetotelluric method or even seismic refraction tomography). In all of them, it has been verified that the soil fundamental frequency is related to the contact between the bottom of the Neogene sediments and bedrock. The expression proposed by Ibs-Von Seht and Wohlenberg (1999) shows the best fit for a broad range of frequencies (Macau et al., 2018). Fig. 7B presents the bedrock topography from the values of the soil fundamental frequency and the equation proposed by Ibs-Von Seht and Wohlenberg (1999). Near the Vallès fault there is a sharp contrast of the soil fundamental frequencies. Thus, NW of the supposed Vallès fault trace there are no sediments and SE of the fault trace there is a step gradient reaching a sediment thickness of $400 \mathrm{~m}$ at $500 \mathrm{~m}$ from the fault. From this point the sediment thickness increases to the SE up to reaching $1200 \mathrm{~m}$ sediment thickness close to the end of the profile.

\subsection{Magnetotelluric inversion and results}

After rotating the MT data to the obtained strike angle of $60^{\circ} \mathrm{N}$, we

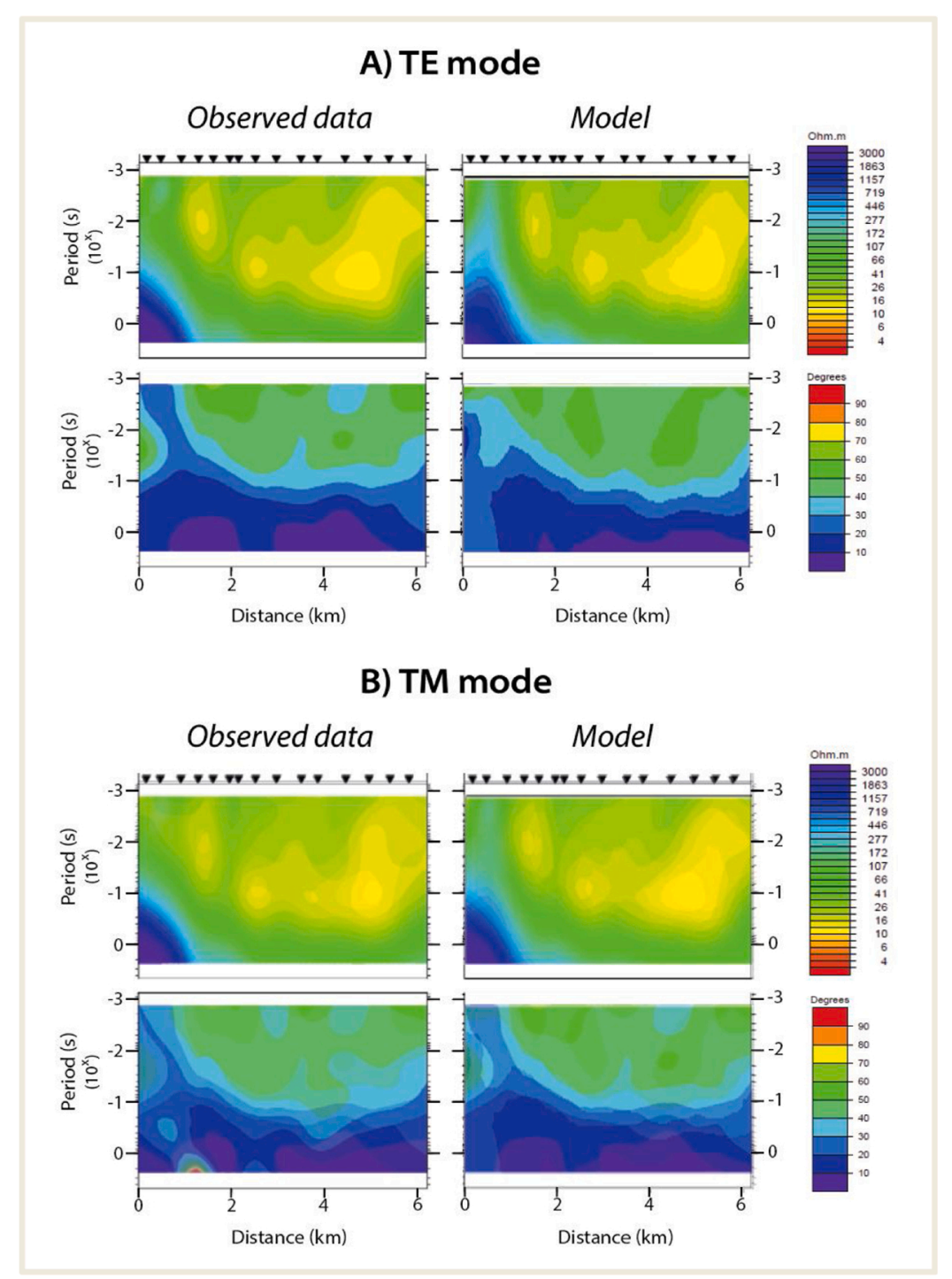

Fig. 8. Apparent resistivity (top) and phase (bottom) pseudosections of observed data and model responses for the TE (A) and TM (B) mode. 
assigned the TE and TM modes to the main impedance components, and the related apparent resistivities and phases.

Simultaneous 2D inversions of TM and TE apparent resistivities and phases were undertaken using the nonlinear conjugate-gradient algorithm of Rodi and Mackie (2001), implemented in the Winglink software (Geosystem SRL). This algorithm simultaneously searches for the model which trades off the lowest overall RMS misfit with the smallest lateral and vertical conductivity gradients in a regularized manner. On average, we fit the logarithm of the apparent resistivity data to within $10 \%$, and the phases to within $2.9^{\circ}$. We used data from 15 MT stations - see Fig. S3 of Supplementary material (station MT2 was discarded because it was too near to the station MT3, and therefore, redundant). A final rms 1.2 was achieved. The initial model was a homogeneous half-space of 100 $\Omega \mathrm{m}$, with a mesh of 89 horizontal cells and 134 vertical cells, neither structural features nor conductivity discontinuities were imposed. Fig. 8A and B compare the resistivity and phase pseudosections of the observed data and model responses. Figure S4 of Supplementary material shows the apparent resistivity and phases curves comparison between the raw data and model responses for the whole dataset. The resulting final model is shown in Fig. 9, where the results of HVSR, as well as the boreholes information (IGME, 1986, 1984a, 1982), are also plotted. For the HVSR results, the maximum and the minimum limits of the bedrock depth have been calculated considering the standard deviation of the fit (black vertical lines in Fig. 9).

In the next lines, we present the description of the main geoelectrical bodies (Fig. 9: R1, C1, C2, and R2) and a general interpretation for these units. A more detailed interpretation will be presented in the Discussions section.

- R1: In the north-northwestern part of the model there is a geoelectrical unit which presents the highest resistivity values $(>3000$ $\Omega \mathrm{m})$. These values can be observed from the shallow structures to the deep parts of the model in his area. This high resistivity unit corresponds to the outcropping granitic materials of the Prelitoral range. - C1: To the SE of R1, there is a subvertical band with lower resistivity values. The resistivity values increase gradually with depth, from $100 \Omega \mathrm{m}$ to $500 \Omega \mathrm{m}$. This unit is assumed to be the fault plain and its associated fractured zone.

- C2: The model presents a near surface conductive geoelectrical unit. This unit has a wedge geometry, with its thickness increasing towards the SSE (from $500 \mathrm{~m}$ of thickness in the north-northwestern part to $1250 \mathrm{~m}$ in the southeastern part). The resistivity values vary from $1 \Omega \mathrm{m}$ to $200 \Omega \mathrm{m}$. This upper unit is associated to the Miocene sediments which fill the basin (alluvial fans of shales sandstones and conglomerates).

- R2: Below the previous conductive unit (C2) there is a resistive zone with values between $500 \Omega \mathrm{m}$ and $3000 \Omega \mathrm{m}$. In this case, we should consider that the high conductivity values of the $\mathrm{C} 2$ unit could affect the determination of the resistivity value underneath.

\subsection{Gravity inversion and results}

The residual anomaly map (Fig. 6C) shows a clear WSW-ENE geometry with negative values which are associated to the Vallès basin. Towards the NNW, the increasing values would be related to the Prelitoral range, which is characterized by denser materials (igneous and metamorphic Paleozoic rocks). The Vallès fault, which separates the Prelitoral range and the Vallès basin, should be traced in the steeper parts of the map, where the contour lines are closer. Towards the SSE the contour lines are not as close, so the contact between the Vallès basin and the Litoral range seems to be more gradual.

Fig. 6C also shows SW-NE variations in the negative anomaly, within the basin, which can be associated to lateral changes of basement depth. The lower values, and therefore, the major thickness of the basin are located close to our study area.

A 2-D forward model was constructed over the NNW-SEE profile, identical to the location of the MT-HVSR 2D model (Fig. 9). To create this geological model from the physical characteristics, we used the GMSYS (Gemperle et al., 1991) profile modeling tool in Geosoft software. The procedure employed for forward modeling can be summarized in the following steps: (1) construction of a model from a priori geometry and density of the rock type; (2) fitting the model response to the observed data, and (3) refine the geometrical and physical parameters of the model. It is important to consider that this software results in a unique density value for each unit (instead of a range of density values), so the final densities should be regarded with caution.

As starting geometries to constrain the model we used the HVSR - MT profile (Fig. 9) and the three exploration boreholes S1, S3 and S6 (IGME, 1986, 1984a, 1982), dividing the model in the four main units (R1, C1, $\mathrm{R} 2, \mathrm{C} 2$ ). For the observed data, we extracted from the residual anomaly map (Fig. 6C), 42 representative points along the profile.

The first results of forward density modeling showed considerable differences between computed and observed gravity anomalies. These differences were minimized by adding more layers inside the $\mathrm{C} 2$ and a

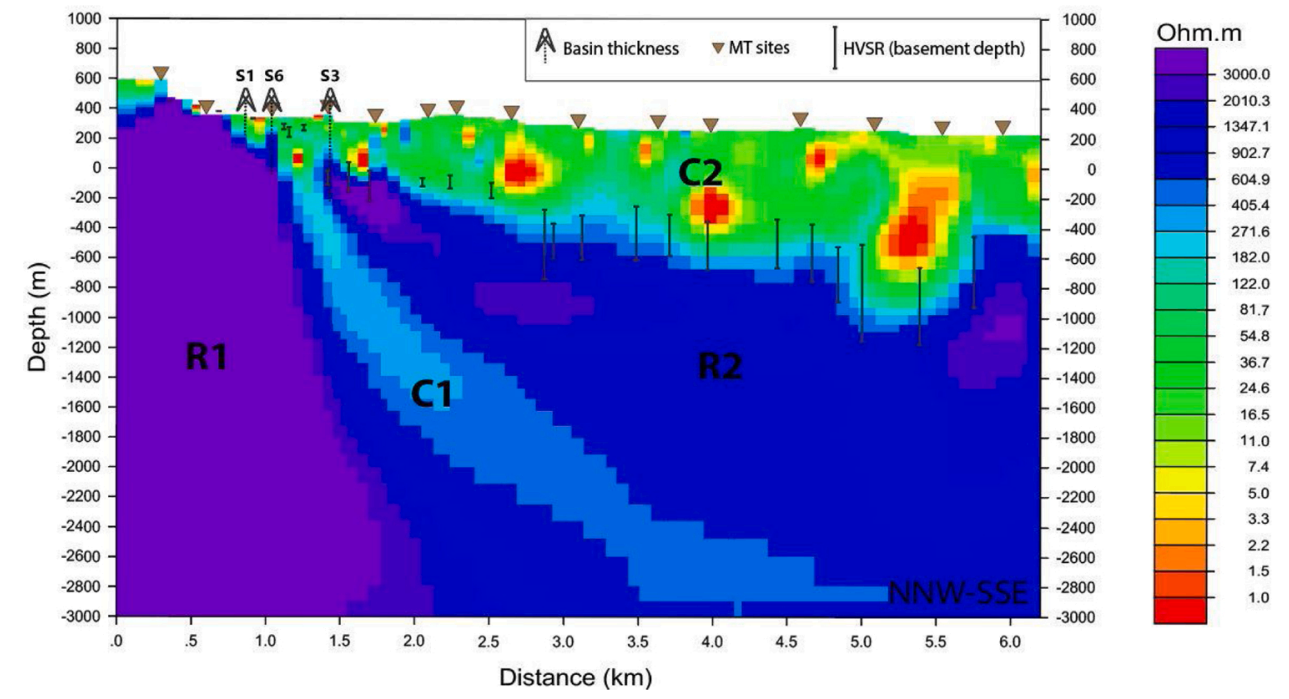

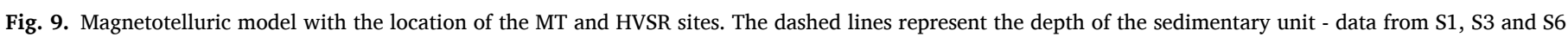

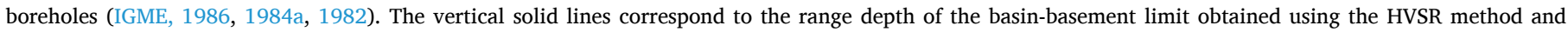
considering the standard deviation of the fit. 
superficial layer in the upper left part of the R1. The criteria used for the differentiation of this new layers were the rounded low-resistivity bodies of the C2, and the low-resistivity anomaly in the left margin of the model (Fig. 9).

The final model was obtained through trial-and-error data fitting, partially fixing the geometry of the bodies, and inverting the density values. The final density model with the best fit (Fig. 10), and consistent with the previous geological and geophysical data (Figs. 2 and 9), shows a good tendance, with a low error value. Even that, in the northwestern part of the profile, some deviations between the observed data and the inversion curve can be observed. These adjustment issues correspond with the vertical presence of different density units, making it difficult to set a better fit for the calculated curve. This final density model presented in Fig. 10 can be divided into four major bodies:

- D1: this first major body comprises the D1_a, _b, _c, and _d minor bodies. These bodies have densities between $2.08 \mathrm{~g} / \mathrm{cm}^{3}$ and $2.84 \mathrm{~g} /$ $\mathrm{cm}^{3}$. The high-density bodies (D1_b and D1_d), are related to the high conductivity parts of the basin (high-conductivity anomalies in C2, Fig. 9), and they appear as isolated bodies rather than in laterally continuous layers.

- D2: this second unit, located underneath the basin, has a density of $3.08 \mathrm{~g} / \mathrm{cm}^{3}$, the highest density value. Although in the MT-HVSR model (Fig. 9) there are some resistivity variations in this unit, the density model fits well with a unique density value. This homogeneity could be due to the low sensitivity of the density method at great depths or because there are not significant density changes.

- D3: this third unit has a density value of $2.55 \mathrm{~g} / \mathrm{cm}^{3}$. This body has a low-density value compared to the rest of units at these greater depths.

- D4: this forth major body includes the D4_a $\left(2.25 \mathrm{~g} / \mathrm{cm}^{3}\right)$ and D4_b $\left(2.85 \mathrm{~g} / \mathrm{cm}^{3}\right)$ minor bodies. In this case we have a high-density body with a small upper lower-density part in the north-northwestern margin.

\section{Discussion}

\subsection{La Garriga-Samalús geological units}

In this section we will combine all the obtained geophysical results in order to create a new geological model of the studied area. We have considered the compiled values of density and electrical resistivity (Manger and Nolan, 1963; Schon, 2015; Tenzer et al., 2011; Wald et al., 2013), as well as the geological map (Fig. 2), to assign the following geological units to our models: the Miocene basin, the Prelitoral range unit, the Vallès Fault Zone, and the Paleozoic basement (Table 2).

\subsubsection{Miocene basin}

In Fig. 11 we have compared the resistivity and density values of the sedimentary bodies (D1_a, b, $c$, and $d$, in Fig. 10) with compiled values of density and electrical resistivity for shales, sandstones, and conglomerates (Schon, 2015).

The D1_c and D1_d bodies are in the shales and sandstones ranges, but the D1_a and D1_b bodies are practically out of any range. Although their high-density values would link them with sandstones or conglomerates, the electrical resistivity values are very low. We have two proposals: deposits with high shales content, or water saturated sands and conglomerates. Considering the S3 exploration borehole (Fig. 3B), which recorded $560 \mathrm{~m}$ of Miocene basin without reaching the basement (IGME, 1984a), we could relate these bodies to sandy and conglomeratic lenses of the Miocene series. In the boreholes report (IGME, 1984a) the Miocene unit is described, in general, as a clayey-arkosic and conglomeratic unit, mostly impermeable; but beyond the $450 \mathrm{~m}$, in S3, they detected sandy and conglomeratic lenses saturated in hot water $\left(60^{\circ} \mathrm{C}\right)$. Therefore, the low-resistivity values could be related to the presence of hot water in these permeable lenses.

In the Vallès-Penedès basin, all the sedimentary sequence of the Miocene consists mainly of proximal to distal-margin alluvial-fan sediments (Cabrera and Calvet, 1996; Gibert and Casanovas-Vilar, 2011; Roca et al., 1999). Specifically, our profile would be a section of the

Table 2

Summary of geological units and their electrical resistivity and density values.

\begin{tabular}{lll}
\hline GEOLOGICAL UNIT & $\begin{array}{l}\text { Electrical resistivity }(\Omega \mathrm{m})( \\
\text { Fig. 9) }\end{array}$ & $\begin{array}{l}\text { Density }\left(\mathrm{g} / \mathrm{cm}^{3}\right) \\
\text { (Fig. 10) }\end{array}$ \\
\hline Miocene basin (Mc) & C2: $1-200$ & $\begin{array}{l}\text { D1a, b, c, d: } \\
2.08-2.84\end{array}$ \\
& & D4: 2.67 \\
Prelitoral Range (PLR) & R1: $>3000$ & D3: 2.27 \\
Vallès fault zone (VZF) & C1: $100-500$ & D2: 2.63 \\
Paleozoic basement & R2: $500-3000$ & \\
(B) & & \\
\hline
\end{tabular}

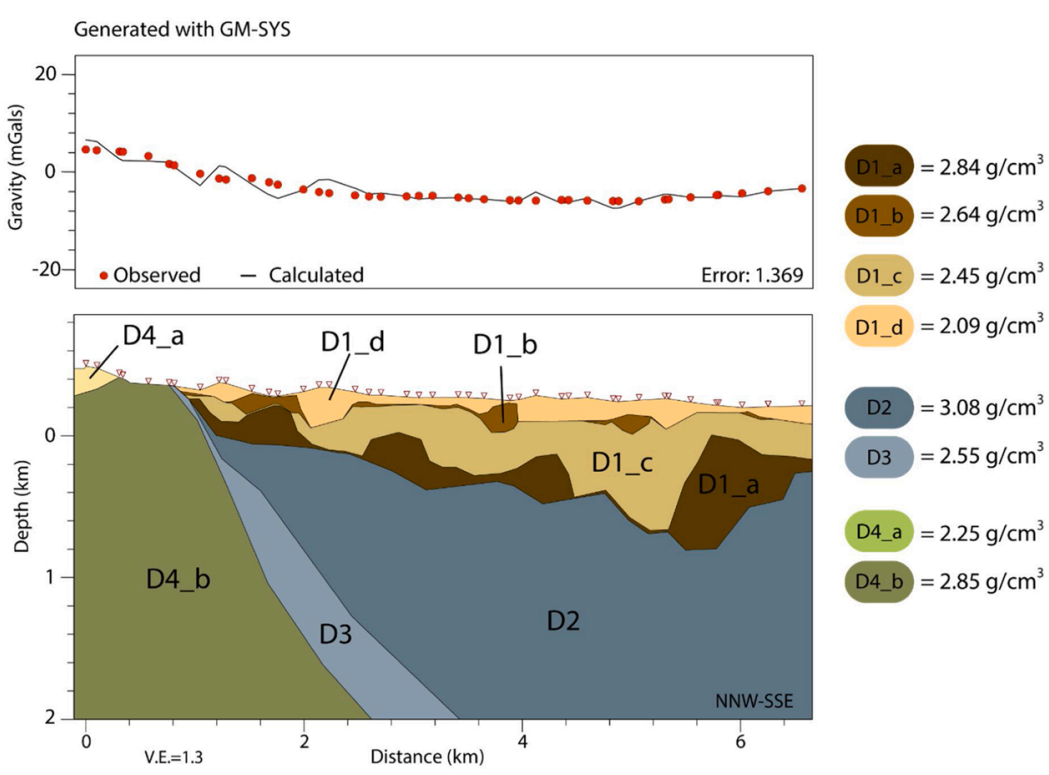

Fig. 10. Density model obtained from the gravity data inversion and constrained by the electrical resistivity model (Fig. 9), and the IGME exploration boreholes (IGME, 1986, 1984a, 1982). 


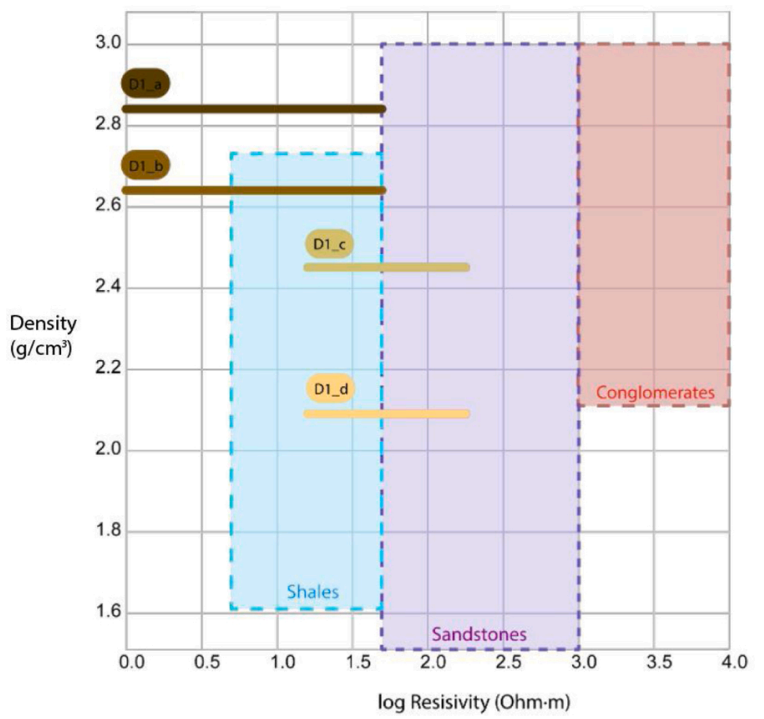

Fig. 11. Miocene sedimentary bodies of the density model (Fig. 10), plotted with the compiled density and resistivity values (Manger and Nolan, 1963; Schon, 2015; Tenzer et al., 2011; Wald et al., 2013) for shales (blue area), sandstones (purple area) and conglomerates (red area). (For interpretation of the references to colour in this figure legend, the reader is referred to the web version of this article).

proximal area of an alluvial fan, where the major supply direction comes from the northeast, perpendicular to our section (Roca et al., 1999). The geometry of this sedimentary unit is in line with the geometries of a typical alluvial fan depositional landform (Fig. 12). Precisely, the D1_a and D1_b bodies could be related to the coarse-grain deposits of the proximal area of an alluvial fan.

\subsubsection{Prelitoral range unit}

In Fig. 13 we have considered the rest of non-sedimentary units. In this figure we can associate the Prelitoral unit to the bodies D4_a and D4_b (R1 in Fig. 9), which correspond to the Paleozoic granodiorite and the altered Paleozoic metamorphic units, respectively. The granodiorite in the NNW part of the profile, with high resistivity and density values, thrusts the Paleozoic metamorphic materials as it can be observed in the geological map (Fig. 2).

\subsubsection{Paleozoic basement}

This unit corresponds to the R2 / D2 bodies, located under the Miocene basin. In Fig. 13 we can observe that this unit has a high-density value. In fact, the density value is $0.08 \mathrm{~g} / \mathrm{cm}^{3}$ higher than any of the ranges set. Obviously, this unit must have a high-density value since it is located at great depths. Even so, we should still consider that the unique value given by the software may have an error range.

This unit shows a broad range of electrical resistivity values, which could be due to the different rock composition, the porosity, the fracture

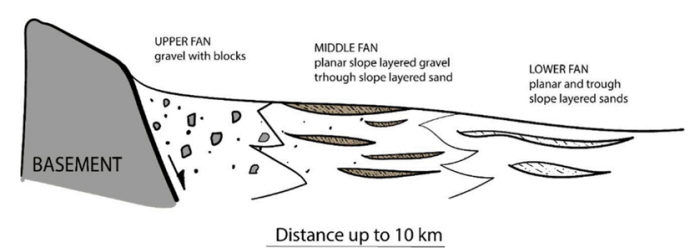

Fig. 12. Cross-section through a generalized alluvial fan. A large amount of gravel with rocks in the proximal range or upper fan whereby gravel, particularly in the distal fans, typically contain muddy matrix. There is a clear reduction in grain size toward the lower part of fans (Modified from Haldar and Tišljar, 2014; Moscariello, 2018). degree, the temperature, the fluid content, and/or the mineral content. Even so, the low resistivity values of the Miocene basin could cause a screening effect on the underneath layers.

This basement body is an undifferentiated unit because it does not outcrop, therefore we do not know if it is formed by the Paleozoic metamorphic series, by the Paleozoic intrusive rocks (like the granodiorite), or both (Fig. 14A). Furthermore, if we take into account the exploration reports made by the Geological Survey of Spain (IGME, 1977), they considered that under the Miocene basin filling, there may be a thick conglomeratic unit related to the alluvial fans (Fig. 14B). Although the density and resistivity may not give us a clear differentiation between conglomerates and the Paleozoic rocks, we have interpreted that this high-resistivity and high-density body would be the Paleozoic basement. We consider that the electrical contrast between R2 and C2 (Fig. 9) is too high to be generated by the same sedimentary process and having similar grain sizes. Furthermore, our gravity map (Fig. 6) as well as the gravity inversion profile (Fig. 10) are consistent with our hypothesis.

\subsubsection{Vallès Fault Zone (VFZ)}

The D3 / C1 body is related to the Vallès Fault Zone (VFZ). Its low density and resistivity (C1 in Fig. 9) match with the results obtained in boreholes (IGME, 1986, 1984a, 1982), which detected a cataclastic zone with thermal circulation fluid evidences.

Fracturing and weathering increase the porosity of rock and consequently, reduces the bulk density; but also, if thermal water is present, the resistivity decrease. Therefore, this conductive body could act as the main path for the hot fluids.

\subsection{A new geometry for the Valles basin}

One of the main results of this work is the determination of basinbasement limit geometry. The depth of the basement has been confirmed from the HVSR results and the MT model. We have also shown that the gravimetric anomaly is compatible with the observed geometry.

In previous studies of the Catalan Coastal Ranges, the maximum thickness of the Miocene deposits were imaged next to the Vallès fault (Gaspar-Escribano et al., 2004; Roca, 1994; Santanach et al., 2011), and some authors have extrapolated this geometry from southwestern parts of the basin to this study area (i.e. Fernàndez and Banda, 1988). In contrast, our results show a gradual increasing thickness of the Miocene unit, from the Vallès fault to the center of the basin. The geometry of the basin of our 2D model, which has a kind of stepwise morphology, could related this increasing thickness of the basin to other minor faults which dip in the same direction as the Vallès fault, in other words, it could be related to synthetic faults (Fig. 14A).

Our results confirm the existence of lateral changes along the Valles Fault Zone since this model differs from the previous ones made in other parts of the basin (Gaspar-Escribano et al., 2004; Roca et al., 1999; Santanach et al., 2011) (i.e. Figs. 1B and 4). As it is seen in the gravity data, the basin thickness changes laterally along the valley. This could reveal a more complex inner structure, with faults parallel to our profile direction. At the same time, this inner structure could condition the presence of the thermal anomalies in only some specific parts of the Vallès basin. So, although we have described this basin geometry in La Garriga-Samalús area, different models could coexist in different parts of the Vallès-Penedès basin.

\subsection{La Garriga-Samalús geothermal system}

An ideal geothermal system is formed by (1) an important heat source, (2) a geological formation which acts as a reservoir and (3) geological units or structures which act as seal layer (Gupta, 1980). A previous study (Fernàndez and Banda, 1990) demonstrated that force convection is the only mechanism capable of explaining this isolated 


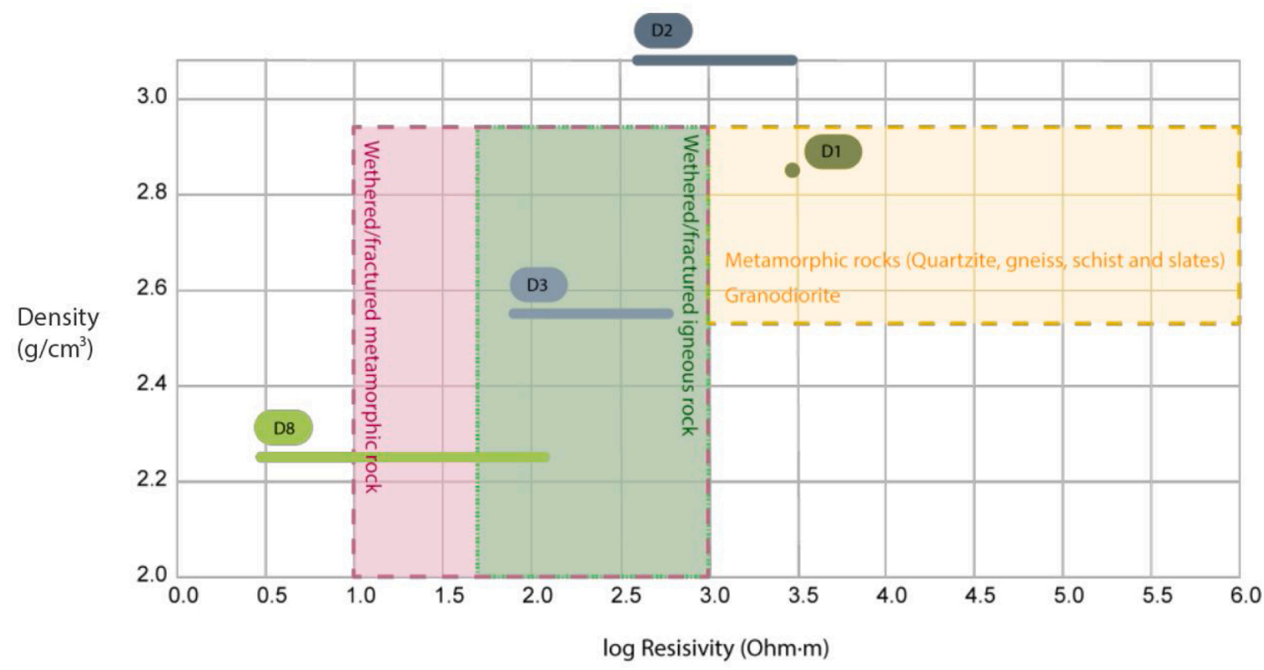

Fig. 13. Non-sedimentary bodies of the density model (Fig. 10), plotted with the compiled density and resistivity values (Manger and Nolan, 1963; Schon, 2015; Wald et al., 2013) for weathered/fractured metamorphic rocks (red area), weathered/fractured igneous rocks (green area), and granodiorite and metamorphic rocks which can be found near the study area (yellow area). (For interpretation of the references to colour in this figure legend, the reader is referred to the web version of this article).
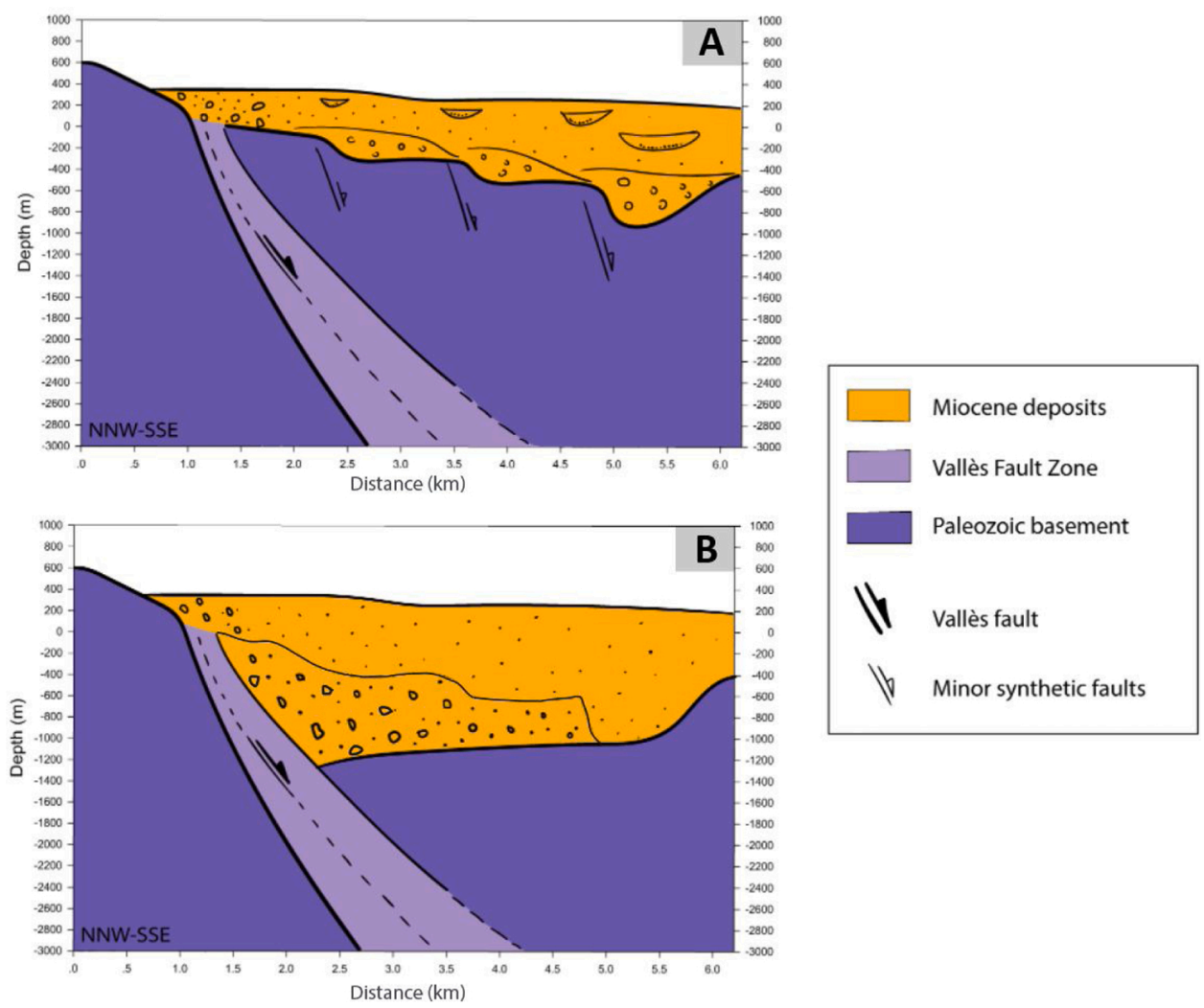

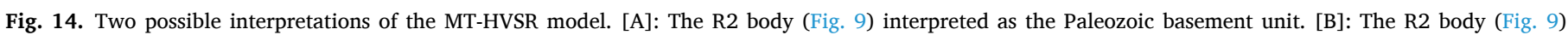
interpreted as thick and compact conglomeratic deposits (IGME, 1977).

high geothermal gradient in La Garriga-Samalús area. The only condition would be a deep and slow descending path, and a conduit which allows a rapid ascent.

The structural characterization of this work is a key point for La Garriga-Samalús geothermal study, which has allowed the identification of this high-conductivity and low-density body, set as the Vallès Fault Zone (VFZ) (Fig. 15). The VFZ could act as a reservoir as well as the main ascending path for the hot fluids, and the impermeable layers of the Miocene basin could act as the seal layer in some parts of the system. On the other hand, the infiltration path has not been detected in our models, although in previous works was set in the Prelitoral Range (Fernàndez and Banda, 1990, 1988).
Furthermore, in terms of exploitation of geothermal energy, the permeable facies of the Miocene basin could not be ignored. In the electrical resistivity model (Fig. 9), potential saturated water zones have been detected, in addition to the hot meteoric water registered in the exploration boreholes (IGME, 1984a).

\section{Conclusions}

The present integrated geophysical study demonstrates that the combination of different geophysical methods, based on different physical properties, are an efficient option during the preliminary phase of the geothermal exploration. 


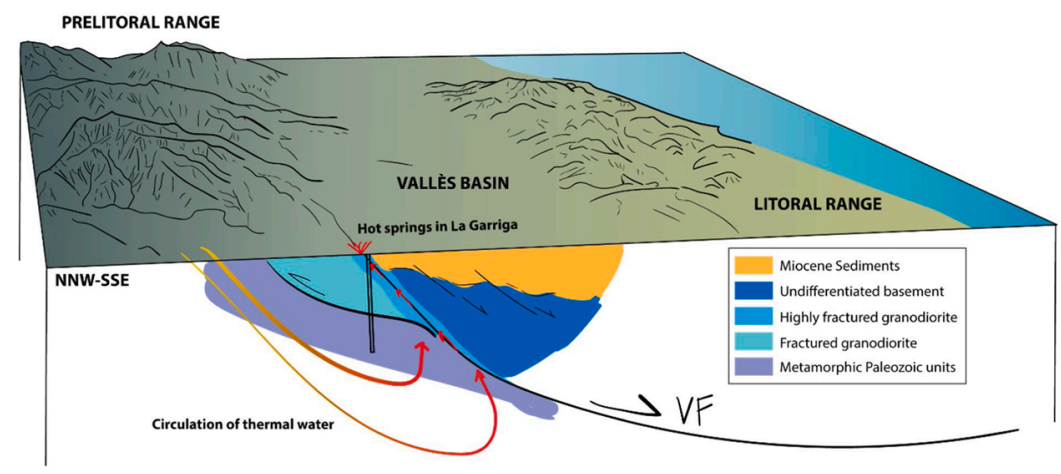

Fig. 15. Conceptual model of the La Garriga-Samalús geothermal system, with the new basin geometry. *Not to scale.

We have presented a multi-physics characterization of the La Garriga-Samalús geothermal system to create a new conceptual model. The HVSR, MT, and gravity results and the final joint interpretation have allowed the identification of four main bodies: (1) the Paleozoic basement, (2) the Vallès Fault Zone, (3) the Prelitoral range unit, and (4) the Miocene deposits. These results have also imaged a new geometry for the basin-basement limit located between 500 and $1250 \mathrm{~m}$ depth.

The final model is consistent with the available geological information of the area, although new structural and geological approaches have been defined. The new results indicate that in this area, the basin thickness increases gradually from the Vallès normal fault towards the south-east of the basin following a stepwise morphology, instead of having a roll-over geometry. At the same time, this new basin geometry could indicate the presence of minor synthetic faults. Although we propose this new geometry for the basin, the geology of the basement as well as the possible minor geological structures are not fully resolved. The interpretation of the $\mathrm{R} 2$ body remains in question because resistivity of compacted coarse grain conglomerates could be high enough (Schon, 2015), although the gravity and the HVSR interpretations do not corroborate the great fault displacement.

The geological and structural characterization of that geothermal system is the first step to try to understand the relevance of the geometry of the basin and its thickness in the geothermal fluid flow. The actual geothermal model fits with our geological model. The Vallès Fault Zone is confirmed as the main path as well as the reservoir for the hot fluids. Likewise, the coarse-grained permeable layers of the Miocene alluvial fans, which are in contact with this geothermal reservoir, should not be ignored as a potential secondary thermal reservoir.

\section{Data availability}

Datasets related to this article can be obtained asking to the corresponding author (gmitjanas@ub.edu).

\section{CRediT authorship contribution statement}

G. Mitjanas: Conceptualization, Methodology, Investigation, Writing - original draft, Visualization. J. Ledo: Conceptualization, Methodology, Investigation, Resources, Writing - original draft, Visualization. A. Macau: Methodology, Investigation, Writing - original draft, Visualization. G. Alías: Conceptualization, Methodology, Investigation, Writing - review \& editing. P. Queralt: Conceptualization, Methodology, Investigation, Resources, Supervision, Writing - review \& editing. F. Bellmunt: Investigation, Writing - review \& editing. Ll. Rivero: Investigation, Writing - review \& editing, Resources. A. Gabàs: Investigation, Writing - review \& editing. A. Marcuello: Investigation, Resources, Writing - review \& editing. B. Benjumea: Investigation, Writing - review \& editing. A. Martí: Investigation, Writing - review \& editing. S. Figueras: Investigation.

\section{Declaration of Competing Interest}

The authors declare that they have no known competing financial interests or personal relationships that could have appeared to influence the work reported in this paper.

\section{Acknowledgements}

This research was funded by the GEO-URBAN project (ERANETGEOTHERMICA project no. 73117 and PCI2018-092943 Spanish Government - Ministerio de Ciencia, Innovación y Universidades); and the PIXIL project (project no. EFA362/19, co-financed by the INTERREG POCTEFA program of the European Regional Development Fund, and the University of Barcelona).

Mitjanas, G., also acknowledges the economic support from the University of Barcelona, for its pre-doctoral fellowship (APIF-2019).

\section{Appendix A. Supplementary data}

Supplementary material related to this article can be found, in the online version, at doi:https://doi.org/10.1016/j.geothermics.2021.10 2067.

\section{References}

Abdelfettah, Y., Sailhac, P., Larnier, H., Matthey, P.D., Schill, E., 2018. Continuous and time-lapse magnetotelluric monitoring of low volume injection at Rittershoffen geothermal project, northern Alsace - France. Geothermics 71, 1-11.

Arango-Galván, C., Prol-Ledesma, R.M., Flores-Márquez, E.L., Canet, C., Villanueva Estrada, R.E., 2011. Shallow submarine and subaerial, low-enthalpy hydrothermal manifestations in Punta Banda, Baja California, Mexico: geophysical and geochemical characterization. Geothermics 40, 102-111.

Ars, J.M., Tarits, P., Hautot, S., Bellanger, M., Coutant, O., Maia, M., 2019. Joint inversion of gravity and surface wave data constrained by magnetotelluric: application to deep geothermal exploration of crustal fault zone in felsic basement. Geothermics 80, 56-68.

Banwell, C.J., 1970. Geophysical techniques in geothermal exploration. United Nations Symposium on the Development and Utilization of Geothermal Resources, Pisa, Italy.

Banwell, C.J., 1973. Geophysical methods used in geothermal exploration. Geothermal Energy. Review of Research and Development. UNESCO, pp. 41-48.

Bard, P.-Y., 1985. Les effets de site d'origine structurale: Principaux résultats experimentaux et théoriques. In: Davidovici, V. (Ed.), Genie Parasismique, pp. 223-238.

Bard, P.-Y., 1999. In: Irikura, K., Kudo, K., Okada, H., Sasatami, T. (Eds.), Microtremor Measurement: A Tool for Site Effect Estimation?, pp. 1251-1279.

Bard, P.-Y., SESAME-Team, 2004. Guidelines for the Implementation of the H/V Spectral Ratio Technique on Ambient Vibrations-Measurements, Processing and Interpretations, SESAME European Research Project EVG1-CT-2000-00026. deliverable D23.12.

Bartrina, M.T., Cabrera, L., Guimerà, J., Roca, E., Jurado, M.J., 1992. Evolution of the central Catalan margin of the Valencia trough (western Mediterranean). Tectonophysics 203, 219-247.

Benjumea, B., Macau, A., Gabas, A., Bellmunt, F., Figueras, S., Cirés, J., 2011. Integrated geophysical profiles and H/V microtremor measurements for subsoil characterization. Near Surf. Geophys. 9, 413-425.

Benjumea, B., Macau, A., Gabàs, A., Esquerda, M., Figueras, S., 2014. Improving near surface characterization by combining reprocessed vintage seismic and geophysical 
passive datasets. Near Surf. Geosci. 2014 - 20th Eur. Meet. Environ. Eng. Geophys. 14-18.

Benson, R., Yuhr, L., Kaufmann, R., 2003. Some considerations for selection and successful application of surface geophysical methods. 3rd Int. Conf. Geophys. 8-12.

Bertran, J., Tarragó, M., 1996. Síntesi estratigràfica del Vallès Oriental. Lauro 11, pp. 54-78.

Bodvarsson, G., 1970. Evaluation of geothermal prospects and the objectives of geothermal exploration. Geoexploration 8, 7-17.

Cabrera, L., 1981. Influencia de la tectónica en la sedimentación continental de la cuenca del Vallés-Penedés (provincia de Barcelona, España) durante el Mioceno inferior. Acta Geológica Hispánica 16, 165-171.

Cabrera, L., Calvet, F., 1996. Onshore Neogene record in NE Spain: Vallès-Penedès and El Camp half-grabens (NW Mediterranean). In: Friend, P., Dabrio, C. (Eds.), Tertiary Basins of Spain: The Stratigraphic Record of Crustal Kinematics. Cambridge University Press, pp. 97-105.

Calcagno, P., Baujard, C., Guillou-Frottier, L., Dagallier, A., Genter, A., 2014. Estimation of the deep geothermal potential within the Tertiary Limagne basin (French Massif Central): an integrated 3D geological and thermal approach. Geothermics 51, 496-508.

Canals, A., Albert, J., Ayora, C., 1989. El sistema geotérmico de la Garriga-Samalús: comparaciones con sistemas hidrotermales fósiles. Geogaceta.

Cardellach, E., Canals, À., Grandia, F., 2003. Recurrent hydrothermal activity induced by successive extensional episodes: the case of the Berta F-(Pb-Zn) vein system (NE Spain). Ore Geol. Rev. 22, 133-141.

Casas, A., Torné, M., Banda, E., 1987. Mapa gravimètric de Catalunya 1:500.000.

Chambefort, I., Buscarlet, E., Wallis, I.C., Sewell, S., Wilmarth, M., 2016. Ngatamariki Geothermal Field, New Zealand: Geology, geophysics, chemistry and conceptual model. Geothermics 59, 266-280.

Chave, A.D., Jones, A.G., Mackie, R., Rodi, W., 2012. The Magnetotelluric Method. Cambridge University Press, Cambridge.

Delgado, J., López Casado, C., Estévez, A., Giner, J., Cuenca, A., Molina, S., 2000. Mapping soft soils in the Segura river valley (SE Spain): a case study of microtremors as an exploration tool. J. Appl. Geophys. 45, 19-32.

Di, Q., Shi, K., Li, Y., Wang, R., Fu, C., An, Z., 2006. Successful applications of CSAMT for deep geothermal exploration in urban areas. In: 2006 SEG Annual Meeting. Society of Exploration Geophysicists, New Orleans, pp. 820-824.

Escalas, M., Queralt, P., Ledo, J., Marcuello, A., 2013. Polarisation analysis of magnetotelluric time series using a wavelet-based scheme: a method for detection and characterisation of cultural noise sources. Phys. Earth Planet. Inter. 218, 31-50.

Fäh, D., Kind, F., Giardini, D., 2001. A theoretical investigation of average HIV ratios. Geophys. J. Int. 145, 535-549.

Fernàndez, M., Banda, E., 1988. Aproximacion a la anomalia geotérmica de La Garriga Samalus (Vallès - Penedès). Acta Geológica Hispánica 23, 1-20.

Fernàndez, M., Banda, E., 1990. Geothermal Anomalies in the Valles-Penedes graben master fault: convection through the horst as a possible mechanism. J. Geophys. Res. 95, 4887-4894.

Gabàs, A., Macau, A., Benjumea, B., Queralt, P., Ledo, J., Figueras, S., Marcuello, A., 2016. Joint audio-magnetotelluric and passive seismic imaging of the Cerdanya Basin. Surv. Geophys. 37, 897-921.

Gallardo, L.A., Fontes, S.L., Meju, M.A., Buonora, M.P., De Lugao, P.P., 2012. Robust geophysical integration through structure-coupled joint inversion and multispectral fusion of seismic reflection, magnetotelluric, magnetic, and gravity images: example from Santos Basin, offshore Brazil. Geophysics 77, 237-251.

Gallart, J., Dañobeitia, J.J., Rojas, H., Diaz, J., 1990. Features of deep crustal structure and the onshore-offshore transition at the Iberian flank of the Valencia trough (Western Mediterranean). J. Geodyn. 12, 233-252.

Gamble, T.D., Goubau, W.M., Clarke, J., 1979. Magnetotellurics with a remote magnetic reference. Geophysics 44, 53-68.

Garambois, S., Sénéchal, P., Perroud, H., 2002. On the use of combined geophysical methods to assess water content and water conductivity of near-surface formations. J. Hydrol. 259, 32-48.

García-Yeguas, A., Ledo, J., Piña-Varas, P., Prudencio, J., Queralt, P., Marcuello, A., Ibañez, J.M., Benjumea, B., Sánchez-Alzola, A., Pérez, N., 2017. A 3D joint interpretation of magnetotelluric and seismic tomographic models: the case of the volcanic island of Tenerife. Comput. Geosci.

Gaspar-Escribano, J.M., Garcia-Castellanos, D., Roca, E., Cloetingh, E., 2004. Cenozoic vertical motions of the Catalan Coastal ranges (NE Spain): the role of tectonics, isostasy, and surface transport. Tectonics 23, 1-18.

Gemperle, M., Conrad, G., Sargen, M.Y., Starr, S., 1991. Geosoft GM-SYS. Version 1.8. Northwest Geophys. Assoc. Inc., New York.

Georgsson, L.S., 2009. Geophysical Methods Used in Geothermal Exploration, 50, pp. 227-249.

Gibert, J.M., Casanovas-Vilar, I., 2011. Contexto geológico del Mioceno de la cuenca del Vallès-Penedès. Paleontol. i Evol. Memòria Espec. 6, 55-80.

Groom, R.W., Bailey, R.C., 1989. Decomposition of magnetotelluric impedance tensors in the presence of local three-dimensional galvanic distortion. J. Geophys. Res.

Gupta, H.K., 1980. Geothermal resources: an energy alternative. Geothermal Resources: An Energy Alternative. Elsevier Scientific Pub. Co.

Haldar, S.K., Tišljar, J., 2014. Precipitation systems of major sedimentary bodies - collector rocks of oil and gas. Introduction to Mineralogy and Petrology. Elsevier, pp. 233-260.

Hammer, S., 1939. Terrain corrections for gravimeter stations. Geophysics 4, 184-194.

Hermans, T., Nguyen, F., Robert, T., Revil, A., 2014. Geophysical methods for monitoring temperature changes in shallow low enthalpy geothermal systems. Energies 7, 5083-5118.
Hersir, G.P., Bjornsson, A., 1991. Geophysical Exploration for Geothermal Resources: Principles and Application, p. 94.

Hunt, T.M., Bromley, C.J., Risk, G.F., Sherburn, S., Soengkono, S., 2009. Geophysical investigations of the Wairakei Field. Geothermics 38, 85-97.

Ibs-Von Seht, M., Wohlenberg, J., 1999. Microtremor measurements used to map thickness of Soft sediments. Bull. Seismol. Soc. Am. 89, 250-259.

ICGC, 2006. Vallès Oriental. Mapa geològic comarcal de Catalunya 1:50.000.

IGC, 2012. Mapa gravimètric de Catalunya 1:250.000.

IGME, 1977. Fase preliminar de prospección de recursos geotérmicos de baja entalpía en el Vallés (Barcelona).

IGME, 1982. Informe sobre el seguimiento técnico del sondeo SAMALUS-1.

IGME, 1984a. Proyecto de investigación geotérmica en el Vallés mediante sondeos de reconocimiento y síntesis hidrogeotérmica. Control geotermico de los sondeos SAMALUS 2 (3), 4 y 5.

IGME, 1984b. Proyecto de investigación geotérmica en el Valles mediante sondeos de reconocimiento y síntesis hidrogeotérmica. Síntesis hidrogeológica del Vallés y La Selva.

IGME, 1985. Proyecto de investigación geotérmica en el Vallés mediante sondeos de reconocimiento y síntesis hidrogeotérmica, p. 355.

IGME, 1986. Proyecto de seguimiento geológico del sondeo de reconocimiento geotérmico SAMALUS-6 (1000 m) (Vallès - Barcelona).

Jousset, P., Haberland, C., Bauer, K., Arnason, K., 2011. Hengill geothermal volcanic complex (Iceland) characterized by integrated geophysical observations. Geothermics 40, 1-24.

Junge, A., 1996. Characterization of and correction for cultural noise. Surv. Geophys. 17, 361-391.

Kana, J.D., Djongyang, N., Raïdandi, D., Njandjock Nouck, P., Dadjé, A., 2015. A review of geophysical methods for geothermal exploration. Renew. Sustain. Energy Rev. 44, 87-95.

Kane, M.F., 1962. A comprehensive system of terrain corrections using a digital computer. Geophysics 27, 455-462.

Kearey, P., Brooks, M., Hill, I., 2002. An Introduction to Geophysical Exploration, 3rd editio. ed. Blackwell Science.

Khodayar, M., Björnsson, S., 2014. Fault ruptures and geothermal effects of the second earthquake, 29 May 2008, South Iceland Seismic Zone. Geothermics 50, 44-65.

Kirkby, A., Heinson, G., Holford, S., 2016. Imaging fracture permeability using magnetotellurics. ASEG Ext. Abstr. 2016, pp. 1-8.

Kraft, T., Mai, P.M., Wiemer, S., Deichmann, N., Ripperger, J., Kästu, P., Bachmann, C., Fäh, D., Wössner, J., Giardini, D., 2009. Enhanced geothermal systems: mitigating risk in urban areas. Eos (Washington DC) 90, 273-274.

Lachet, C., Bard, P.Y., 1994. Numerical and theoretical investigations on the possibilities and limitations of Nakamura's technique. J. Phys. Earth 42, 377-397.

Lee, W.H.K., Stewart, S.W., 1981. Principles and Applications of Networks. A G 1981.

Leeuwen, Wvan, 2016. Geothermal Exploration Using the Magnetotelluric Method. Faculty of Geosciences - Utrecht University.

Lewis, M.R., Haeni, F.P., 1987. Use of Surface Geophysical Techniques to Detect Fractures in Bedrock - An Annotated Bibliography. US Geol. Surv. Circ.

Low, U., Absar, A., Duraiswami, R., Singh, A., 2020. Geophysical exploration of TuralRajwadi group of hot springs, West Coast Geothermal Province, Maharashtra, India and its implications. Geothermics 88, 101874.

Lüschen, E., Wolfgramm, M., Fritzer, T., Dussel, M., Thomas, R., Schulz, R., 2014. 3D seismic survey explores geothermal targets for reservoir characterization at Unterhaching, Munich, Germany. Geothermics 50, 167-179.

Macau, A., Benjumea, B., Gabàs, A., Bellmunt, F., Figueras, S., 2018. Geophysical measurements for site effects characterisation in the urban area of Girona, Spain. Near Surf. Geophys. 16, 340-355.

Mahajan, A.K., Galiana-Merino, J.J., Lindholm, C., Arora, B.R., Mundepi, A.K., Rai, N., Chauhan, N., 2011. Characterization of the sedimentary cover at the Himalayan foothills using active and passive seismic techniques. J. Appl. Geophys. 73, 196-206.

Maithya, J., Fujimitsu, Y., 2019. Analysis and interpretation of magnetotelluric data in characterization of geothermal resource in Eburru geothermal field, Kenya. Geothermics 81, 12-31.

Mandal, A., Basantaray, A.K., Chandroth, A., Mishra, U., 2019. Integrated geophysical investigation to map shallow surface alteration/fracture zones of Atri and Tarabalo hot springs, Odisha, India. Geothermics 77, 24-33.

Manger, G.E., Nolan, T.B., 1963. Porosity and Bulk Density of Sedimentary Rocks: Contributions to Geochemistry.

Manzella, A., 1973. Geophysical Methods in Geothermal Exploration. Italian National Research Council. International Institute for Geothermal Research, Pisa, Italy.

Martí, J., Mitjavila, J., Roca, E., Aparicio, A., 1992. Cenozoic magmatism of the valencia trough (western mediterranean): relationship between structural evolution and volcanism. Tectonophysics 203, 145-165.

McNeice, G.W., Jones, A.G., 2002. Multisite, multifrequency tensor decomposition of magnetotelluric data. Geophysics.

Meidav, T., Tonani, F., 1976. A critique of geothermal exploration techniques. Proceedings of the 2nd UN Symposium on the Development and Use of Geothermal Resources, pp. 1143-1154.

Moeck, I., Bloch, T., Graf, R., Heuberger, S., Kuhn, P., Naef, H., Sonderegger, M., Uhlig, S., Wolfgramm, M., 2015. The St. Gallen project: development of fault controlled geothermal systems in urban areas. Proc. World Geotherm. Congr. 2015, $1-5$.

Morelli, C., Gantar, C., Honkasalo, T., McConnel, R.K., Tanner, J.G., Szabo, B., Uotila, U., Whalen, C.T., 1972. The International Gravity Standardisation Net 1971 (IGSN71). Spec. Publ. No. 4. 
Moscariello, A., 2018. Alluvial fans and fluvial fans at the margins of continental sedimentary basins: geomorphic and sedimentological distinction for geo-energy exploration and development. Geol. Soc. Spec. Publ. 440, 215-243.

Nagy, D., 1966. The gravitational attraction of a right rectangular prism. Geophysics 31, 362-371.

Nakamura, Y., 1989. A method for dynamic characteristics estimations of subsurface using microtremors on the ground surface. Q. Rept. RTRI 30, 25-33.

Nieto, I.M., Martín, A.F., Blázquez, C.S., Aguilera, D.G., García, P.C., Vasco, E.F., García, J.C., 2019. Use of 3D electrical resistivity tomography to improve the design of low enthalpy geothermal systems. Geothermics 79, 1-13.

Nowell, D.A.G., 1999. Gravity terrain corrections - an overview. J. Appl. Geophys. 42, $117-134$.

Pálmason, G., 1976. Geophysical methods in geothermal exploration. Proceedings of the 2nd UN Symposium on the Development and Use of Geothermal Resources $1175-1184$.

Peacock, J.R., Thiel, S., Heinson, G.S., Reid, P., 2013. Time-lapse magnetotelluric monitoring of an enhanced geothermal system. Geophysics 78, 121-130.

Rao, D.B., 1986. Modelling of sedimentary basins from gravity anomalies with variable density contrast. Geophys. J. R. Astron. Soc. 84, 207-212.

Roca, E., 1994. La evolución geodinámica de la Cuenca Catalano-Balear y áreas adyacentes desde el Mesozoico hasta la actualidad. Acta Geológica Hispánica 29, $3-25$.

Roca, E., Guimerà, J., 1992. The Neogene structure of the eastern Iberian margin: structural constraints on the crustal evolution of the Valencia trough (western Mediterranean). Tectonophysics 203, 203-218.

Roca, E., Sans, M., Cabrera, L., Marzo, M., 1999. Oligocene to Middle Miocene evolution of the central Catalan margin (northwestern Mediterranean). Tectonophysics 315, 209-229.

Rodi, W., Mackie, R.L., 2001. Nonlinear conjugate gradients algorithm for 2-D magnetotelluric inversion. Geophysics 66, 174-187.

Rodríguez, F., Pérez, N.M., Padrón, E., Melián, G., Piña-Varas, P., Dionis, S., Barrancos, J., Padilla, G.D., Hernández, P.A., Marrero, R., Ledo, J.J., Bellmunt, F., Queralt, P., Marcuello, A., Hidalgo, R., 2015. Surface geochemical and geophysical studies for geothermal exploration at the southern volcanic rift zone of Tenerife, Canary Islands, Spain. Geothermics 55, 195-206.

Sàbat, F., Roca, E., Muñoz, J.A., Vergés, J., Santanach, P., Sans, M., Masana, E., Estévez, A., Santisteban, C., 1997. Role of extension and compression in the evolution of the eastern margin of Iberia: the ESCI-València Trough seismic profile. Rev. Soc. Geol. España 8, 431-448.
Sanchez-Guzman, J., Garcia De la Noceda-Marquez, C., 2005. Geothermal energy development in Spain - country update report. Proceedings World Geothermal Congress, Antalya, Turkey, pp. 24-29.

Santanach, P., Casas, J.M., Gratacós, O., Liesa, M., Muñoz, J.A., Sàbat, F., 2011. Variscan and Alpine structure of the hills of Barcelona: geology in an urban area. J. Iber. Geol. 37, 121-137.

Schiel, K., Baume, O., Caruso, G., Leopold, U., 2016. GIS-based modelling of shallow geothermal energy potential for $\mathrm{CO} 2$ emission mitigation in urban areas. Renew. Energy 86, 1023-1036.

Schon, J.H., 2015. Physical properties of rocks. Fundamentals and principles of petrophysics. Developments in Petroleum Science, 2nd ed.

Shah, M., Sircar, A., Vaidya, D., Sahajpal, S., Chaudhary, A., Dhale, S., 2015. Overview of geothermal surface exploration methods. Ijariie 1, 55-64.

Simpson, R.W., Jachens, R.C., 1989. Chapter 3: gravity methods in regional studies. Mem. Geol. Soc. Am. 172, 35-44.

Soengkono, S., Bromley, C., Reeves, R., Bennie, S., 2013. Geophysical techniques for low enthalpy geothermal exploration in New Zealand. Explor. Geophys. 2011, 37-40.

Szarka, L., 1988. Geophysical aspects of man-made electromagnetic noise in the Earth - a review. Surv. Geophys. 9, 287-288.

Tenzer, R., Sirguey, P., Rattenbury, M., Nicolson, J., 2011. A digital rock density map of New Zealand. Comput. Geosci. 37, 1181-1191.

Thanassoulas, C., Xanthopoulos, N., 1991. Location of possibly productive geothermal fracture zones/faults using integrated geophysicals methods over lesvos island geothermal field, Greece. Geothermics 20, 355-368.

Vidal, N., Gallart, J., Danobeitia, J.J., 1995. Contribution of the ESCI-Valéncia trough wide-angle data to a crustal transect in the NE iberian margin. Rev. la Soc. Geol. Espana.

Viseras, C., 2002. Principles of sedimentary basin analysis (third edition). Sediment. Geol. 152, 327-328.

Wald, J.A., Graham, R.C., Schoeneberger, P.J., 2013. Distribution and properties of soft weathered bedrock at $\leq 1 \mathrm{~m}$ depth in the contiguous United States. Earth Surf. Process. Landforms 38, 614-626.

Yousefi, H., Roumi, S., Ármannsson, H., Noorollahi, Y., 2019. Cascading uses of geothermal energy for a sustainable energy supply for Meshkinshahr City, Northwest, Iran. Geothermics 79, 152-163.

Zhang, N., Qin, Q., He, L., Jiang, H., 2012. Remote sensing and GIS based geothermal exploration in southwest Tengchong, China. Int. Geosci. Remote Sens. Symp. 5364-5367.

Zonge, K.L., Hugues, L.J., 1991. Controlled source audio-frequency magnetotellurics. Electromagn. Methods Appl. Geophys., p. 2. 